\title{
11. ZONAL STRATIGRAPHY AND PLANKTONIC FORAMINIFERS OF PALEOGENE DEPOSITS OF THE ATLANTIC OCEAN TO THE WEST OFF AFRICA (DEEP SEA DRILLING PROJECT, LEG 41)
}

\author{
Valery A. Krasheninnikov, Geological Institute of the USSR Academy of Sciences, Moscow, USSR \\ and \\ Uwe Pflaumann, Geologisch-Paläontologisches Institut der Universität Kiel, Olshausenstr. 40/60, \\ 23 Kiel, Federal Republic of Germany
}

\section{SUMMARY}

Paleogene sediments have been drilled at five sites off northwest Africa during Leg 41. Site 366 on the Sierra Leone Rise is characterized by its rather monotonous sedimentary record of biogenic carbonate pelagic sediments throughout the Paleogene. Using planktonic foraminifer stratigraphy no hiatuses occur. With the exception of two early Paleogene zones which had been not recovered due to drilling difficulties, all foraminifer zones were sampled. Therefore the stratigraphic completeness of the deposits on the Sierra Leone Rise offers a reference section of Paleogene for the eastern North Atlantic. Optimal preservation conditions occur only in the Oligocene part, while Eocene and Paleocene are represented by mostly harder rocks (i.e., limestones, siliceous limestones, and porcellanites), with only occasional interbeds of calcareous clays and marls.

Sometimes zonal boundaries could not be precisely defined. For zonation we used the tropical belt scheme, although a number of species representative of the Paleogene tropical-subtropical belt are missing or strongly reduced in abundance.

The Paleogene of the Cape Verde Basin (Site 367) shows only very rare and scattered occurrences of planktonic foraminifers and most of the samples are barren of them. Just in the lower Eocene, some samples contain planktonic foraminifers.

Site 368 (Cape Verde Rise) is poorer in fossil remains of Paleogene age. No planktonic foraminifers have been recognized in the Paleogene sediments, which contain noncarbonate clays and claystones.

On the continental slope off Spanish Sahara (Site $369)$ the stratigraphic record is incomplete. Some 20 meters of middle Eocene chalk and limestones overlie Late Cretaceous sediments, and are separated by a gap from the upper Eocene nanno marls, with a thickness of about 5 meters. Then follows a continuous section of Oligocene nanno marls, which contain excellently preserved planktonic foraminifers, though in reduced abundances.

In the Deep basin off Morocco (Site 370) Paleogene deep-water deposits contain only sparse assemblages of planktonic foraminifers. The record is further reduced by spot coring. However, there is a discontinuity within a 10-meter uncored interval at the base of the Paleogene-Paleocene overlying early Cenomanian. A gap occurs between Paleocene and Eocene as well. The Eocene, at least a 200-meter thick sequence of calcareous clays interbedded with coarser clastic materials and porcellanites and cherts, contains mainly poor planktonic foraminifer assemblages. The presence of Oligocene age sediment in the calcareous clays is based on planktonic foraminifer content.

The paleontological part contains short comments on planktonic foraminifer species recovered in the Oligocene sediments. It is accompanied by plates, which show selected species and include the ultrastructure of their tests. Table 2 condenses the stratigraphic record of all planktonic foraminifers recorded in the Paleogene of all Leg 41 sites.

\section{INTRODUCTION}

DSDP Leg 41 investigated the eastern part of the Atlantic Ocean along the continent of Africa (Figure 1). Paleogene deposits occur in six holes drilled at five sites. These holes are associated with geological structures that underwent different history of geological development. Accumulation depths of Paleogene sediments were different. Therefore Paleogene deposits have different lithologies, various assemblages of planktonic foraminifers, and different degrees of stratigraphic completeness.

Paleogene deposits from Leg 41 give a very complete idea about the Paleogene stratigraphy of the northeast Atlantic Ocean. The data increase our knowledge of Paleogene biostratigraphy, based on planktonic foraminifers, for this region. On the western coast of Africa (Morocco, Spanish Sahara, Senegal) the distribution of Paleogene deposits is rather limited. The sediments are shallow water deposits with large benthic foraminifers, especially of late Eocene and Oligocene ages.

\section{REGIONAL STRATIGRAPHY}

The geographical position of the holes, depth of the ocean in places of drilling, penetration of holes into sediments, the thickness of Paleogene deposits, and the number of cores taken within the Paleogene are shown in Table 1. Stratigraphy of Paleogene deposits in each of the holes from the south (Sierra Leone Rise) towards the north (Morocco basin) is given below.

\section{Sierra Leone Rise}

Two holes were drilled on the rise-366 and 366A. The former is a continuation of the latter. Hole $366 \mathrm{~A}$ drilled Quaternary, Neogene, and Oligocene deposits (to the Globigerina ampliapertura Zone). The hole was 


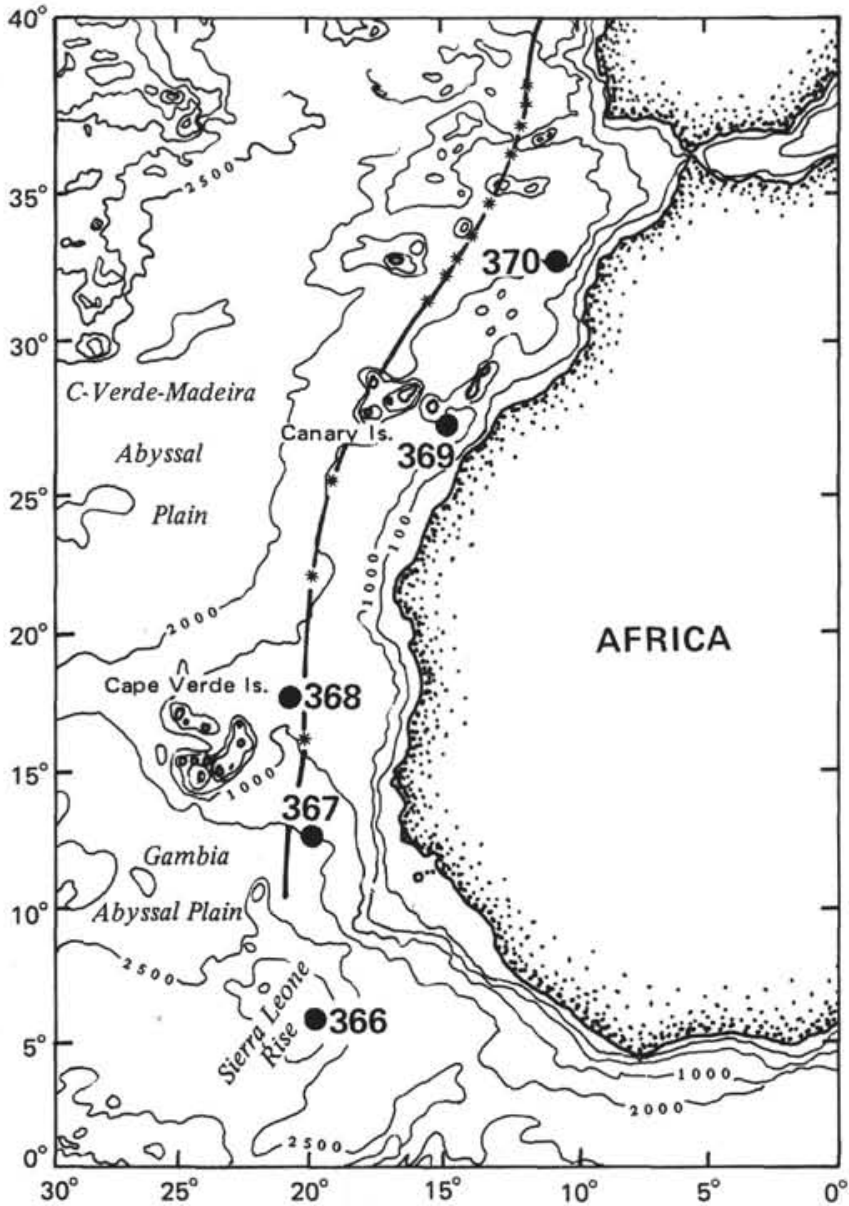

Figure 1. Location of Leg 41 Sites 366, 367, 368, 369, and 370.

continuously cored to 367 meters; Hole 366 drilled deposits as old as Maestrichtian at the base; beginning from a depth of 366 meters (sediments of the Globigerina ampliapertura Zone) and it was continuously cored. The Paleogene section is about 588 meters thick from its lower boundary with the Upper Cretaceous (Maestrichtian) to the upper boundary with the Neogene (lower Miocene).

The Paleogene deposits are subdivided into three lithologic units: The lower unit, about 161 meters thick, is composed of greenish gray, pale gray, and pale greenish limestones, clayey limestones, and marls with subordinate interbeds of calcareous clays and siliceous limestones in the upper part. These deposits include
Paleocene and the lowermost Eocene (up to the Globorotalia aragonensis Zone). The middle unit, 200 meters thick, is pale gray, pale greenish, and almost white nanno chalk that alternates with clayey limestones, siliceous limestones, and porcellanites. There are numerous interbeds of siliceous sediments. This unit ranges in age from the upper part of the lower Eocene to the middle Eocene. The upper unit, about 227 meters thick, is composed of greenish soft nanno oozes, nanno chalk, and nanno marlstones with subordinate interbeds of calcareous clays. These deposits are upper Eocene and Oligocene in age.

Paleogene sediments of the Sierra Leone Rise are rather monotonous, which suggests relative stability of sedimentation conditions. The deposits are biogenic carbonate pelagic (deep water) sediments, with negligible admixture of terrigenous material.

Based on planktonic foraminifers, the Paleogene of the Sierra Leone Rise contains almost all zonal subdivisions, except for the two lower zones of the Danian stage-the Globorotalia pseudobulloides and Globigerina eugubina zones. The stratigraphic interval of these two zones is not large. We can assume, however, that these two zones are present in the section. Due to drilling difficulties, the interval (up to $18 \mathrm{~m}$ ) separating the Globorotalia trinidadensis (Danian stage) and the Globotruncana contusa (Maestrichtian) zones was drilled but not cored. It is very likely that this interval contains the two above-mentioned Danian zones and the upper part of the Maestrichtian. Thus, a transition from the upper Cretaceous to Paleogene is either gradual, or the sediments of this age are separated by a small gap.

Across the Paleogene-Neogene boundary, sedimentation was continuous and late Oligocene sediments (the Globorotalia kugleri s. str. 7one) are conformably overlaid by those of early Miocene (the Globigerinoides primordius-Globorotalia kugleri Zone). Stratigraphic completeness of the Paleogene section makes these sediments an important reference section of Paleogene deposits in the tropical eastern Atlantic. In addition to the stratigraphic completeness, the section contains the main three groups of plankton (foraminifers, nannoplankton, radiolarians).

However, the section is characterized by some negative features, too. Only upper Oligocene sediments (the Globorotalia opima, Globigerina ciperoensis, Globorotalia kugleri s. str. zones) contain perfect assemblages of planktonic foraminifers. In the lower part of Oligocene, Eocene, and Paleocene assemblages are

TABLE 1

Data on the Holes of Leg 41

\begin{tabular}{lcccccc}
\hline Hole & Latitude (N) & Longitude (W) & $\begin{array}{c}\text { Depth of } \\
\text { Ocean } \\
(\mathrm{m})\end{array}$ & $\begin{array}{c}\text { Depth of } \\
\text { Penetration } \\
(\mathrm{m})\end{array}$ & $\begin{array}{c}\text { Thickness } \\
\text { of Paleo- } \\
\text { gene } \\
(\mathrm{m})\end{array}$ & $\begin{array}{c}\text { Number of } \\
\text { Cores in } \\
\text { Paleogene }\end{array}$ \\
\hline 366 & $05^{\circ} 40^{\prime} 68^{\prime \prime}$ & $19^{\circ} 51^{\prime} 08^{\prime \prime}$ & 2860 & 850.5 & 475.0 & 49 \\
$366 \mathrm{~A}$ & $05^{\circ} 40^{\prime} 70^{\prime \prime}$ & $19^{\circ} 51^{\prime} 10^{\prime \prime}$ & 2860 & 367.0 & 112.5 & 12 \\
367 & $12^{\circ} 29^{\prime} 21^{\prime \prime}$ & $20^{\circ} 02^{\prime} 83^{\prime \prime}$ & 4748 & 1153.0 & 158.0 & 7 \\
368 & $17^{\circ} 30^{\prime} 43^{\prime \prime}$ & $21^{\circ} 21^{\prime} 23^{\prime \prime}$ & 3367 & 984.5 & ?(up to 465$)$ & ?(up to 35) \\
$369 \mathrm{~A}$ & $26^{\circ} 35^{\prime} 55^{\prime \prime}$ & $14^{\circ} 59^{\prime} 96^{\prime \prime}$ & 1760 & 488.5 & 207.5 & 22 \\
370 & $32^{\circ} 50^{\prime} 25^{\prime \prime}$ & $10^{\circ} 46^{\prime} 56^{\prime \prime}$ & 4216 & 1176.0 & 393.0 & 15 \\
\hline
\end{tabular}


frequently sparse, poorly preserved, and have a poor systematic composition (some foraminifer species and genera representative of the tropical area are absent). Poor preservation of planktonic foraminifers makes it difficult to identify species and even genera and to evaluate ratios of various species in an assemblage. For instance, it is sometimes difficult to differentiate the representatives of Acarinina and Truncorotaloides. Assemblages of planktonic foraminifers provide a reliable establishment of zones, but the boundaries between the adjacent zones are frequently outlined only roughly. This should be considered while analyzing the relationships of the zonal scales based on planktonic foraminifers, nannoplankton, and radiolarians.

Below is given the zonal stratigraphy of Paleogene deposits of the Sierra Leone Rise.

\section{Paleocene}

In Paleocene deposits, which are up to 112 meters thick and range from Samples 366-43-2, 82-84 cm down to $53, \mathrm{CC}$, six zones have been distinguished:

The Globorotalia trinidadensis Zone (Danian Stage) with rare specimens of the index species and abundant $G$. pseudobulloides, Globigerina varianta, $G$. trivialis, $G$. triloculinoides, Chiloguembelina sp. sp. In some samples rare Globorotalia compressa were observed. Minimum thickness is 19 meters. Interval: Cores 366-52 and 36653.

The Acarinina uncinata Zone-its assemblage includes sparse Acarinina uncinata, $A$. inconstans, $A$. indolensis, and $A$. spiralis, accompanied by more abundant Globorotalia pseudobulloides, G. compressa, $G$. quadrata, Globigerina triloculinoides, $G$. varianta, $G$. trivialis, G. edita. Thickness is 6.8 meters. Interval: from $366-51-2,70-72 \mathrm{~cm}$, down to $51, \mathrm{CC}$. In the interval from 51-6, 95-97 cm, down to $51, \mathrm{CC}$ the planktonic foraminifers show a transition to the microfauna of the underlying Globorotalia trinidadensis Zone.

The Globorotalia angulata Zone-characterized by numerous $G$. angulata combined with $G$. pseudobulloides, G. ehrenbergi, G. quadrata, Globigerina triloculinoides, $G$. varianta, $G$. trivialis. Thickness is 2.2 meters. Interval: from 366-51-1, 22-24 cm, down to 36651-2, 22-24 cm.

The Globorotalia pusilla Zone includes abundant numbers of index species, $G$. conicotruncata and $G$. angulata. G. quadrata, G. pseudobulloides, Globigerina triloculinoides, $G$. trivialis, $G$. varianta still occur. Thickness is 5.0 meters. Interval: from 366-50-4, 73-75 $\mathrm{cm}$, down to $50, \mathrm{CC}$.

The Globorotalia pseudomenardii Zone includes the index species, G. velascoensis, $G$. parva, $G$. occlusa, $G$. laevigata, G. apanthesma, G. hispidicidaris, Globigerina nana, $G$. velascoensis, Acarinina mckannai, A. esnaensis, A. intermedia, A. strabocella. In the upper part of the zone is Globorotalia acuta. Thickness is 30 meters. Interval: from $366-47-3,32-34 \mathrm{~cm}$, to $366-53-3,115-117$ $\mathrm{cm}$. The sediments in the interval from 366-50-1, 126$128 \mathrm{~cm}$ to $366-50-3,115-117 \mathrm{~cm}$ contain a poorly preserved microfauna which is transitional to the microfauna of the Globorotalia pusilla Zone.

The Globorotalia velascoensis Zone includes the index species, G. acuta, G. apanthesma, $G$. trichotrocha, $G$. aequa, G. occlusa, Acarinina acarinata, A. primitiva, A. mckannai, A intermedia, A. soldadoensis, A. esnaensis, Globigerina nana, and $G$. velascoensis. Thickness is 39.5 meters. Interval: from $366-43-2,82-84 \mathrm{~cm}$, to $47-2,40-$ $42 \mathrm{~cm}$.

\section{Eocene}

Eocene deposits have a thickness of 315 meters and extend from $366-9, \mathrm{CC}$ to $366-43-1$.

The lower Eocene includes four zones:

The Globorotalia subbotinae Zone includes the index species, $G$. aequa, $G$. wilcoxensis, $G$. formosa gracilis, $G$. apanthesma, Acarinina soldadoensis, A. acarinata, A. intermedia, A. camerata, A. esnaensis, A. pseudotopilensis, Globigerina nana, and G. compressaformis. In the upper part of the zone there is Globorotalia marginodentata. Specimens of Pseudohastigerina wilcoxensis are extremely rare, the first of them having been observed in Sample 366-43-1, 66-68 cm together with sparse Globorotalia acuta. Thickness is 11 meters. Interval: from $366-41, \mathrm{CC}$ to $366-43-1,66-68 \mathrm{~cm}$. Sample $366-43-2,82-84 \mathrm{~cm}$, is characterized by a transitional microfauna-together with upper Paleocene Globorotalia velascoensis, $G$. acuta, etc. Sporadic Globorotalia subbotinae and Acarinina pseudotopilensis occur here as well.

The Globorotalia formosa Zone-its assemblage of planktonic foraminifers consists of the index species, $G$. marginodentata, $G$. lensiformis together with transitional from underlying deposits $G$. formosa gracilis, G. wilcoxensis, G. subbotinae, G. apanthesma, Acarinina soldadoensis, $A$. camerata, $A$. primitiva, $A$. acarinata, A. pseudotopilensis, and Globigerina compressaformis. Thickness is 14.5 meters. Interval: from $366-40-5,117-119 \mathrm{~cm}$, to $366-41-5,51-53 \mathrm{~cm}$.

The Globorotalia aragonensis Zone, where abundant planktonic foraminifers are the index species, Acarinina interposita, A. pseudotopilensis, A. triplex, A. broedermanni, combined with rarer Acarinina soldadoensis, $A$. pentacamerata, Globorotalia caucasica, G. lensiformis, G. quetra, Globigerina eocaena. Interval: from 366-38-1, 84-86 cm to $366-40-3,67-69 \mathrm{~cm}$;

In the subbottom depth interval of 622.5 meters to 679.5 meters (Cores 366-32 to 366-37) the compact nanno chalk with numerous interbeds of porcellanites and siliceous limestones contains impoverished poorly preserved microfauna. Besides the above species of foraminifers, Acarinina gravelli, Globigerina senni, $G$. eocaenica, and $G$. inaequispira were found, Acarinina pentacamerata becoming more common. This interval was attributed to the undifferentiated Globorotalia aragonensis and Globorotalia palmerae zones.

The Globorotalia palmerae Zone in which the most significant component of the fauna is presented by Acarinina pentacamerata, A. aspensis, Globorotalia caucasica, and Globigerina senni. Other species are Globorotalia aragonensis, Acarinina interposita, A. broedermanni, A. triplex, A. pseudotopilensis, Globigerina eocaenica, $G$. pseudoeocaena, $G$. eocaena. Interval: from $366-29-1,71-73 \mathrm{~cm}$ to $366-31, \mathrm{CC}$.

The general thickness of deposits of the Globorotalia aragonensis and the Globorotalia palmerae zones is 109 meters and the interval is from Core $366-19$ to $366-40-3$, 67-69 cm. 
The zonal subdivision of the middle Eocene (thickness $123.5 \mathrm{~m}$ ) is extremely difficult. Calcareous sediments of this age are also characterized by numerous interbeds of hard porcellanites and siliceous limestones with poor assemblages of planktonic foraminifers. In some cases the age can be determined within two adjacent zones only. The following zones have been distinguished in ascending order:

1) The Hantkenina aragonensis Zone with numerous Acarinina bullbrooki and rarer Globorotalia boweri. Among other species of planktonic foraminifers are Acarinina aspensis, A. pentacamerata, A. triplex, A. pseudotopilensis, A. broedermanni, Globorotalia caucasica, Globigerina senni, G. eocaenica. These deposits are certain to be of the middle Eocene age, but their belonging to the Hantkenina aragonensis Zone is conventional. Interval: Core 366-28;

2) The undifferentiated Hantkenina aragonensisGlobigerapsis kugleri zones, where a similar assemblage of planktonic foraminifers as that below occurs-with Acarinina bullbrooki, A. aspensis, Globigerina senni, Globorotalia boweri, etc., but rare Globigerina higginsi, Clavigerinella jarvisi, Globorotalia spinulosa, Truncorotaloides rohri, Acarinina aff. rotundimarginata appear. Interval: Core 366-27;

3) The undifferentiated Globigerapsis kugleriGloborotalia lehneri zones with Acarinina bullbrooki, $A$. aspensis, A. triplex, A. pentacamerata, A. rotundimarginata, Globigerina senni, G. higginsi, G. eocaena, Globigerapsis kugleri, G. index, Truncorotaloides rohri, $T$. topilensis, Globorotalia boweri, G. frontosa, G. spinulosa, G. bolivariana, Hantkenina sp., and sporadic Globorotalia caucasica. Interval: Cores 366-24 to 36626;

4) The undifferentiated Globorotalia lehneriOrbulinoides beckmanni zones, where the assemblages of planktonic foraminifers contain numerous Truncorotaloides rohri, T. topilensis, Acarinina bullbrooki, $A$. rotundimarginata, Globorotalia frontosa combined with rarer Globigerapsis index, G. kugleri, Globigerinatheca barri, Globorotalia spinulosa, $G$. bolivariana, G. spinuloinflata, Globorotaloides suteri, Globigerina senni, G. pseudoeocaena, G. pseudovenezuelana. Small Globorotalia pomeroli described, as a rule, under the name of Globorotalia centralis, become common here. It is the presence of the last species that makes us assume the belonging of sediments to the Orbulinoides beckmanni Zone, too. Interval: Cores 36622 to $366-23$;

5) The Orbulinoides beckmanni Zone with a typical assemblage of planktonic foraminifers-large Globorotalia pomeroli $(=G$. centralis as interpreted by many micropaleontologists), Truncorotaloides rohri, $T$. topilensis, Globorotalia spinuloinflata, G. frontosa, G. bolivariana, Acarinina bullbrooki accompanied by rarer Globigerapsis index, Globigerina senni, G. eocaena, Acarinina rotundimarginata, Globorotalia lehneri. Sporadic specimens of Orbulinoides beckmanni have been found in Samples 366-21-2, 21-23 cm, and 366-213, 68-70 cm. Interval: Core 366-21;

6) The undifferentiated Orbulinoides beckmanniTruncorotaloides rohri zones with numerous $T$. rohri and sporadic $T$. topilensis. Other species of planktonic foraminifers are presented by rare specimens of
Globorotalia spinulosa, G. spinuloinflata, G. frontosa, Globigerapsis index, Acarinina rotundimarginata, Hantkenina dumblei, Globigerinita globiformis. Interval: Core 366-20;

7) The Truncorotaloides rohri Zone-its assemblage of planktonic foraminifers consists of the index species, Globigerapsis index, Globigerinatheca barri, Acarinina aff. rugosoaculeata, Globorotaloides suteri, Globorotalia bolivariana, G. pomeroli, Globigerina pseudovenezuelana, $G$. tripartita, G. praebulloides, G. turcmenica, $G$. galavisi, Pseudohastigerina micra. Interval: from 366$15, \mathrm{CC}$ to $366-19, \mathrm{CC}$.

Though upper Eocene nanno chalk and marls (thickness $57 \mathrm{~m}$ ) are devoid of interbeds of hard siliceous limestones, siliceous microfossils are common. Planktonic foraminifers have a poor systematic composition and do not provide a reliable zonal subdivision:

1) The undifferentiated Globigerapsis semiinvolutaGloborotalia cerroazulensis zones characterized by Globigerina galavisi, G. tripartita, G. angiporoides, G. praebulloides, G. corpulenta, G. pseudovenezuelana, $G$. pseudoampliapertura, Globigerinita unicava, Globorotaloides suteri, Globigerapsis index, G. tropicalis, Globorotalia pomeroli $(=G$. centralis after some authors). Interval: from $366-10-6,20-22 \mathrm{~cm}$, to $366-15-$ 2, $37-39 \mathrm{~cm}$;

2) The Globorotalia "centralis"-Globigerina turritilina zone after the terminology of Blow that terminates the Eocene. This zone includes the first appearance of Globigerina ampliapertura, G. prasaepsis, $G$. officinalis, and Globorotalia permicra, which reaching their flourish in Oligocene. Also occurring are Globorotalia aff. pomeroli (=to $G$. centralis, as interpreted by some micropaleontologists) and rare specimens of Hantkenina, which due to their preservation could not be determined at the species level (up to Sample 366-10-2, $45-47 \mathrm{~cm}$ ), but does not pass into the base of the Oligocene. Other species are Globigerina tripartita, G. galavisi, Globigerinita unicava. Interval: from $366-9, \mathrm{CC}$ to $366-10-5,30-32 \mathrm{~cm}$.

\section{Oligocene}

Oligocene nanno oozes, nanno chalk, and marls reach the thickness of 159 meters. In the lower part of the Oligocene the sparse fauna prevents zonal subdivision, but distinct succession of the zones occurs higher up:

1) The undifferentiated Globigerina tapuriensisGlobigerina sellii zones characterized by $G$. tapuriensis, $G$. ampliapertura, $G$. prasaepsis, $G$. officinalis, $G$. tripartita, G. galavisi, G. pseudovenezuelana, G. winkleri, $G$. senilis, G. ouachitaensis, Globorotalia gemma, G. nana, Globigerinita unicava, Globorotaloides suteri, Pseudohastigerina barbadoensis, Ps. micra, Chiloguembelina sp. Thickness is 30.5 meters. Interval from $366-6-6,48-50 \mathrm{~cm}$ to $366-9-4,32-34 \mathrm{~cm}$. Absence of Globigerina sellii does not allow to differentiate the two zones.

2) The Globigerina ampliaperture Zone with the index species, G. ouachitaensis, $G$. prasaepsis, $G$. angustiumbilicata, G. tripartita, G. galavisi, G. winkleri, $G$. officinalis, G. praebulloides, G. senilis, Globigerinita 
unicava, Globorotaloides suteri, Globorotalia nana, $G$. permicra, Chiloguembelina sp. Thickness is 24 meters. Interval: $366 \mathrm{~A}-39-2,71-73 \mathrm{~cm}$ to $366 \mathrm{~A}-39, \mathrm{CC}$ and downwards in the section: $366-5, \mathrm{CC}$ to $366-6-5,73-75$ $\mathrm{cm}$.

3) The Globorotalia opima Zone, where numerous species are: the index species, G. nana, Globigerina angulisuturalis, G. ouachitaensis, G. angustiumbilicata, G. praebulloides. Common species are Globigerina officinalis, G. galavisi, G. rohri (in Bolli's sense), $G$. tripartita, G. winkleri, Globigerinita unicava, Globorotaloides suteri, Chiloguembelina sp. and relatively rare species are Globigerina prasaepsis, $G$. ciperoensis, $G$. senilis, $G$. venezuelana, $G$. sellii, Globigerinita dissimilis, G. stainforthi praestainforthi, Cassigerinella chipolensis. Thickness is 57 meters. Interval: from $366 \mathrm{~A}-33-2,72-74 \mathrm{~cm}$ down to $366 \mathrm{~A}-39-1$, $81-83 \mathrm{~cm}$;

4) The Globigerina ciperoensis Zone: its assemblage of planktonic foraminifers consists of Globigerina ciperoensis, G. angulisuturalis, G. ouachitaensis, G. angustiumbilicata, $G$. praebulloides, $G$. venezuelana, $G$. galavisi, G. officinalis, G. rohri (in Bolli's sense), Globigerinita unicava, G. dissimilis, G. stainforthi praestainforthi, Globorotaloides suteri, Cassigerinella chipolensis, Globorotalia nana, G. siakensis. Rare Globorotalia pseudokugleri appear in the top of the zone. Thickness is 30 meters. Interval: from 366 A-30-1, $72-74 \mathrm{~cm}$ to $366 \mathrm{~A}-33-1,92-94 \mathrm{~cm}$;

5) The Globorotalia kugleri s. str. Zone, where the most representative components of the foraminifer assemblage are the index species, G. pseudokugleri, $G$. siakensis, Globigerina venezuelana, G. praebulloides, $G$. angustiumbilicata, Globigerinita unicava that are accompanied by less frequent Globorotalia nana, Globigerinita dissimilis, G. stainforthi praestainforthi, Globorotaloides suteri, Cassigerinella chipolensis and sporadic Globigerina bradyi in the top of the zone. Thickness is 17.5 meters. Interval: from 366A-28-2, 62 $64 \mathrm{~cm}$, to $366 \mathrm{~A}-29$, CC.

The Oligocene-Miocene boundary is fixed through the appearance of Globigerinoides primordius combined with Globorotalia kugleri, Globigerina bradyi, G. juvenilis, G. venezuelana; 366A-28-1, 91-93 cm.

\section{Cape Verde Basin, Hole 367}

In the deep-water basin of the Cape Verde islands the Paleogene is represented by quite different deposits. Multi-colored clays, zeolitic clays with flint, radiolarian and diatom clays occur here. The stratigraphic subdivision of these deposits is difficult, since the plankton with a calcareous skeleton is practically absent, and the plankton with a siliceous skeleton is associated to some horizons only.

The Paleogene begins with greenish and reddish clays and silty clays. These may be superimposed by a hiatus on rocks of Cretaceous age, but the exact position of the Cretaceous-Paleogene boundary remains uncertain: above the clays with planktonic Cretaceous foraminifers $(367-15-4,42-44 \mathrm{~cm})$ clays occur $(367-15-2$, $52-54 \mathrm{~cm}$ and $367-15-3,52-54 \mathrm{~cm}$ ), with rare agglutinated foraminifers (Rhabdammina, Silicosigmoilina, Glomospira, Hormosina, Recurvoides). This prevents a satisfactory conclusion about the age of sediments. Higher in the section (Core 367-14) there are clays containing late Paleocene-early Eocene radiolarians (the Bekoma bidartensis Zone). No planktonic foraminifers have been recognized in this member.

Multicolored clays are replaced by gray, greenish gray, and yellowish green zeolitic clays with interbeds of porcellanites and nodules of flint. At the base of zeolitic clays (367-14-2) late Paleocene-early Eocene radiolarians (the Bekoma bidartensis Zone) still occur. Higher in the section (367-13-1), a poor nannoplankton occurs of lowermost Eocene age (the Marthasterites tribrachiatus Zone). The clays of Core 367-12 (the upper part of the lower Eocene) are the richest in planktonic microfossils. They are characterized by radiolarians of the Phormocyrtis striata striata Zone, nannoplankton of the Discoaster lodoensis Zone and planktonic foraminifers of the Globorotalia aragonensis-Globorotalia palmerae zones. Such species as Globorotalia aragonensis, $G$. pseudoscitula, Acarinina pentacamerata, $A$. aspensis, $A$. broedermanni, A triplex, A. pseudotopilensis, Globigerina pseudoeocaena occur within the latter. Further on (Cores 367-11 and 367-10) species Acarinina and Globorotalia are quite sporadic and radiolarians suggest the presence of the upper part of the lower Eocene (the Theocotyle cryptocephala Zone). Finally, in Core 367-9 the calcareous plankton disappear completely, and rare radiolarians suggest middle-upper Eocene age.

The Paleogene (Core 367-8) ends with gray and greenish gray radiolarian-diatom clays of the upper Eocene (the Thyrsocyrtis bromia Zone).

The total thickness of Paleogene deposits is 176 meters. This figure is approximate, as the Paleogene upper boundary is obscure. Radiolarian and diatom clays are overlain by turbidites. In their lower part (thickness $57 \mathrm{~m}$ ) only one core (367-7) was taken and fossil remains were absent. Higher in the section the turbidites are characterized by a heterogeneous assemblage of planktonic foraminifers and nannoplankton showing that their age is not older than middle Miocene. Thus, the lower part of the turbidites can still be assigned to Paleogene (Oligocene).

\section{Cape Verde Rise, Hole 368}

The Paleogene deposits of this region are extremely poor in fossil remains. This prevents making detailed stratigraphy of the Paleogene at this locality.

Albian-Turonian black shales (Core 368-58) and lower Miocene carbonate sediments (Core 368-18) are separated here by a thick stratum $(636 \mathrm{~m})$ of noncarbonate clays (Cores 368-19 to 368-57). Clays and harder claystones have reddish, brown, pale greenish, and gray-green tints, are frequently enriched with sandy and silty material, and pass into sandy and aleuritic clays. These sediments frequently alternate with one another, and the whole section attains a turbiditic character.

The lower part of the section (Cores 368-50 to 36857 , thickness $219 \mathrm{~m}$ ) contains different agglutinated foraminifers (Rhabdammina, Reophax, Rhizammina, Ammodiscus, Glomospira, Saccammina, Trochammina, Trochamminoides, Plectina, Recurvoides, Haplo- 
phragmoides, Hormosina, Rzehakina, Silicosigmoilina, Dorothia), and likely still belongs to the Upper Cretaceous.

Higher in the section (Cores 368-31 to 368-49, thickness $275 \mathrm{~m}$ ), the clays are practically devoid of fossil remains. In only a few samples (368-39, CC, 368$40, \mathrm{CC}, \quad 368-46-3,61-63 \mathrm{~cm}$, were there sporadic occurrences of Rhizammina, Ammodiscus, Trochammina, Saccammina, Rhabdammina, Glomospira, Reophax, Trochamminoides, Haplophragmoides, and Recurvoides. These do not provide reliable determination of age. Stratigraphic data suggest that Paleogene deposits are likely to occur below those of lower Eocene. At least, clays of Sample 368-41-4, 11-13 $\mathrm{cm}$ contain pollen of land plants and microphytoplanktonic cells of Eocene age (Zaklinskaya, this volume).

Only in the upper part of the clay and claystone formation (Cores 368-27 to 368-30, thickness $42 \mathrm{~m}$ ) fossil remains of the lower Eocene occur: radiolarians of the Phormocyrtis striata striata Zone, as well as a sparse nannoplankton of the Marthasterites tribrachiatus-Discoaster lodoensis zones.

The uppermost clays contain no microfauna and flora, except for indefinable casts of benthonic foraminifers. Considering the stratigraphic position of this member, the presence of middle-upper Eocene and Oligocene deposits in its composition is quite probable. The upper part of the barren clays could be of the lower Miocene age.

The position of the lower and upper boundaries of the Paleogene section from the Cape Verde Rise is rather uncertain. Stratigraphy is not complete. The section is poor in microfossils, and the thickness of Paleogene $(417 \mathrm{~m})$ is estimated rather conditionally. No planktonic foraminifers have been recognized in Paleogene sediments from the rise.

\section{Continental Slope off Spanish Sahara, Hole 369A}

On the continental slope off Spanish Sahara the section of Paleogene deposits (209 m thick) is not stratigraphically complete.

Pale gray, slightly clayey nanno chalk and limestones with cherts and porcellanites of the middle Eocene uncomformably overlie (within Core 369A-35) analogous sediments of the late Maestrichtian. The middle Eocene is represented only by the Globorotalia lehneri Zone with abundant planktonic foraminifers-G. lehneri, $G$. spinulosa, $G$. frontosa, $G$. pomeroli $(=G$. centralis after some micropaleontologists), G. spinuloinflata, $G$. bolivariana, $G$. boweri, Acarinina rotundimarginata, A. bullbrooki, Truncorotaloides rohri, $T$. topilensis, Globigerapsis index, G. kugleri, Globigerinatheca barri, Globigerina senni, G. pseudoeocaena, G. eocaena, Pseudohastigerina micra, Clavigerinella akersi, Hantkenina sp. Thickness is 23.7. meters. Interval: from $369 \mathrm{~A}-33-4,61-63 \mathrm{~cm}$ to 369A-35-5, 112-113 cm.

Upper Eocene sediments (greenish gray and brownish nanno marls with abundant siliceous microfossils) are also separated from the middle Eocene by a gap. The thickness of the upper Eocene does not exceed 5 meters. In the lower part of this member planktonic foraminifers are rather poor. In the top their specific composition is more diverse-Globorotalia aff. pomeroli $(=G$. centralis), Globigerina pseudoampliapertura, G. galavisi, G. prasaepsis, $G$. ouachitaensis, G. tripartita, G. senilis, G. pseudovenezuelana, Pseudohastigerina micra, Globorotaloides suteri, and rare Globigerina ampliapertura. The deposits appear to belong to the uppermost upper Eocene-the Globorotalia centralis-Globigerina turritilina Zone as interpreted by Blow. Interval: 369A-32,CC to 369A-33$4,2-4 \mathrm{~cm}$.

The upper Eocene is succeeded by Oligocene pale gray and greenish gray nanno marls (180.5 m thick), where succession of all zones is clear:

The Globigerina tapuriensis Zone with the index species, G. ampliapertura, G. galavisi, G. prasaepsis, $G$. officinalis, $G$. ouachitaensis, G. winkleri, G. senilis, $G$. tripartita, G. praebulloides, G. pseudovenezuelana, Globigerinita unicava, Pseudohastigerina barbadoensis, Ps. micra, Cassigerinella chipolensis, Globorotaloides suteri, Globorotalia permicra, G. nana, G. gemma, Chiloguembelina aff. cubensis. Thickness is 35 meters. Interval: from $369 \mathrm{~A}-29-3,61-63 \mathrm{~cm}$ to $369 \mathrm{~A}-32-4,81-83$ $\mathrm{cm}$.

The Globigerina sellii Zone characterized by the same assemblage of planktonic foraminifers with the index species. Thickness is 12.5 meters. Interval: from 369A28 to 369 A-29-2, 61-63 cm. Since $G$. sellii is observed rarely, the boundary with the Globigerina tapuriensis Zone is conditional;

The Globigerina ampliapertura Zone, where representatives of the genus Pseudohastigerina disappear, Globigerina angustiumbilicata is present, and in the top of the zone sporadic specimens of $G$. angulisuturalis and Globigerinita dissimilis appear. Thickness is 33.5 meters. Interval: from 369A-24-4, 61$63 \mathrm{~cm}$ to $369 \mathrm{~A}-27, \mathrm{CC}$;

The Globorotalia opima Zone, the lower boundary of which is determined by development of numerous $G$. opima and Globigerina angulisuturalis. G. ciperoensis, G. rohri (in Bolli's sense), Globigerinita stainforthi praestainforthi also appear. The typical elements of the foraminiferal assemblage are Globigerina ouachitaensis, $G$. winkleri, $G$. angustiumbilicata, G. praebulloides, $G$. galavisi, G. tripartita, Globorotalia nana, Globorotaloides suteri, Globigerinita unicava, Cassigerinella chipolensis. There are rare specimens of Globigerina officinalis, $G$. senilis, Globigerinita dissimilis, Chiloguembelina aff. cubensis, and in the lower part of the zone-Globigerina prasaepis, G. sellii, and Globorotalia permicra. No specimens of Globigerina ampliapertura have been recognized. Thickness is 80.5 meters. Interval: from 369A-16, CC to 369A-24-3, 61-63 cm;

The Globigerina ciperoensis Zone has an impoverished assemblage of planktonic foraminifers because Globorotalia opima, G. permicra, Globigerina rohri, G. winkleri, G. tripartita, G. officinalis, G. senilis, $G$. prasaepis, Chiloguembelina aff. cubensis from underlying deposits do not pass into this zone. Such species as Globigerina ciperoensis and G. angulisuturalis have been observed almost in all samples; Globorotalia siakensis is a new element of the fauna. Thickness is 19 meters. Interval: Cores 369A-14 and 369A-15.

The uppermost zone of Oligocene age (the Globorotalia kugleri s. str. Zone) was not detected in Hole $369 \mathrm{~A}$, probably because of a poor assemblage of plank- 
tonic foraminifers in the top of the Oligocene. Yet, we cannot exclude the absence of the zone due to a gap in sedimentation.

Thus, the section of Paleogene deposits of Hole 369A contains no Paleocene (including the Danian stage), lower Eocene, a greater part of the middle Eocene (the Hantkenina aragonensis, Globorotalia kugleri, Orbulinoides beckmanni, Truncorotaloides rohri zones), and a greater part of the upper Eocene (the Globigerapsis semiinvoluta and Globorotalia cerroazulensis zones). In fact, the Oligocene is the only complete section.

\section{Deep Basin off Morocco, Hole 370}

Paleogene deep-water deposits in the basin off Morocco are characterized by poor assemblages of planktonic foraminifers. This, together with discontinuous coring presents difficulties for stratigraphic subdivision of the Paleogene.

The Paleogene overlies Upper Cretaceous deposits with a sharp disconformity, as the Paleocene (the Globorotalia pusilla Zone, Core 370-19) is separated from the lower Cenomanian (the Rotalipora apenninica Zone, Core $370-20$ ) by a 10 -meter unsampled interval.

The Paleocene is composed of soft pale gray marls and greenish nanno clays, 19 meters thick.

The following zones have been distinguished on the basis of planktonic foraminifers:

The Globorotalia pusilla Zone with $G$. conicotruncata, G. angulata, Acarinina mckannai, A. sp.sp., Globigerina triloculinoides (370-19,CC);

The Globorotalia pseudomenardii Zone with the index species, G. velascoensis, G. occlusa, G. laevigata, Acarinina mckannai, Globigerina velascoensis, $G$. nana (370-19-1);

The Globorotalia velascoensis Zone with the index species, G. occlusa, G. acuta, G. aequa, G. apanthesma, $G$. convexa, G. trichotrocha, Acarinina acarinata, $A$. mckannai, A. soldadoensis, Globigerina velascoensis, $G$. nana $(370-18, C C)$.

The Paleocene-Eocene boundary passes within the core catcher of Core 370-18, the Eocene basal layers being attributed to the Globorotalia aragonensisGloborotalia palmerae zones.

Thus, a gap encompassing the Globorotalia subbotinae and Globorotalia formosa zones was fixed between Paleocene and Eocene. The Eocene is composed of gray greenish and yellowish brown calcareous clays with numerous interbeds of silty and sandy and more coarse arenaceous and gravel material. The latter impart a turbidite character to the sediments. Lower and middle Eocene clays alternate with porcellanites and contain cherty nodules. Minimal thickness of the Eocene is 218 meters.

The lower Eocene, as was mentioned above, belongs to the undifferentiated Globorotalia aragonensisGloborotalia palmerae zones and is characterized by Globorotalia aragonensis, Acarinina pentacamerata, $A$. aspensis, A. interposita, $A$. soldadoensis, $A$. pseudotopilensis, A. triplex, A. gravelli, A. broedermanni, Globigerina eocaenica, G. senni, G. eocaena, Pseudohastigerina wilcoxensis. Interval: Cores 370-13 to 370-18.
A poor assemblage of planktonic foraminifers -Acarinina bullbrooki, A. pentacamerata, A. broedermanni, Truncorotaloides rohri, Globorotalia boweri, G. frontosa, G. pomeroli, Globigerina senni, G. eocaena, Pseudohastigerina micra-was recognized in middle Eocene. This assemblage does not allow a zonal subdivision of sediments. Interval: Cores 370-7 to 37012.

The clays of overlying Core 370-6 are generally devoid of planktonic foraminifers, whereas sporadic radiolarians and nannoplankton determine the age of sediments within the upper Eocene-Oligocene.

Core $370-5$ was taken 95 meters higher in the section, and is characterized by microfauna of the Globorotalia opima Zone (Oligocene): the index species, G. nana, Globigerina angulisuturalis, G. tripartita, Globorotaloides suteri, Globigerinita unicava, $G$. dissimilis, Cassigerinella chipolensis. It is composed of gray greenish calcareous clays with silty material.

The minimal thickness of Paleogene sediments in Hole 370 is 342 meters. However, it could be greater, considering that Oligocene (Core 370-5) is separated from the lower Miocene (Core 370-4) by a 95-meter uncored interval.

Correlation of Paleogene deposits penetrated by Holes $366,366 \mathrm{~A}, 367,368,369 \mathrm{~A}$ and 370 is presented in Figure 2.

\section{ZONAL STRATIGRAPHY, PALEOECOLOGICAL PATTERNS OF FORAMINIFERS, AND GEOLOGICAL HISTORY OF THE PALEOGENE}

Regional stratigraphic studies of the area between the Sierra Leone Rise and Morocco Basin enables a conclusion to be made concerning Paleogene zonation, based on planktonic foraminifers. The same succession of planktonic foraminiferal species has been established here as in the Paleogene of other regions of the tropical and subtropical belt (Table 2). This makes it possible to use a standard foraminifer zonal scale of the Paleogene. It includes:

Paleocene-the Globorotalia trinidadensis (Hole 366), Acarinina uncinata (Hole 366), Globorotalia angulata (Hole 366), Globorotalia pusilla (Holes 366, 370), Globorotalia pseudomenardii (Holes 366, 370), Globorotalia velascoensis (Holes 366, 370) zones;

Lower Eocene-the Globorotalia subbotinae (Hole 366), Globorotalia formosa (Hole 366), Globorotalia aragonensis (Hole 366), Globorotalia palmerae (Hole 366) zones;

Middle Eocene-the undifferentiated Hantkenina aragonensis and Globigerapsis kugleri (Hole 366) zones, the Globorotalia lehneri (Hole 369A), Orbulinoides beckmanni (Hole 366), Truncorotaloides rohri (Hole366) zones;

Upper Eocene-the undifferentiated Globigerapsis semiinvoluta-Globorotalia cerroazulensis (Hole 366) zones, the Globorotalia "centralis"-Globigerina turritilina (Holes 366, 369A) zone;

Oligocene-the Globigerina tapuriensis (Hole 369A), Globigerina sellii (Hole 369A), Globigerina ampliapertura (Holes 366, 369A), Globorotalia opima (Holes 366A, 369A, 370), Globigerina ciperoensis (Holes 


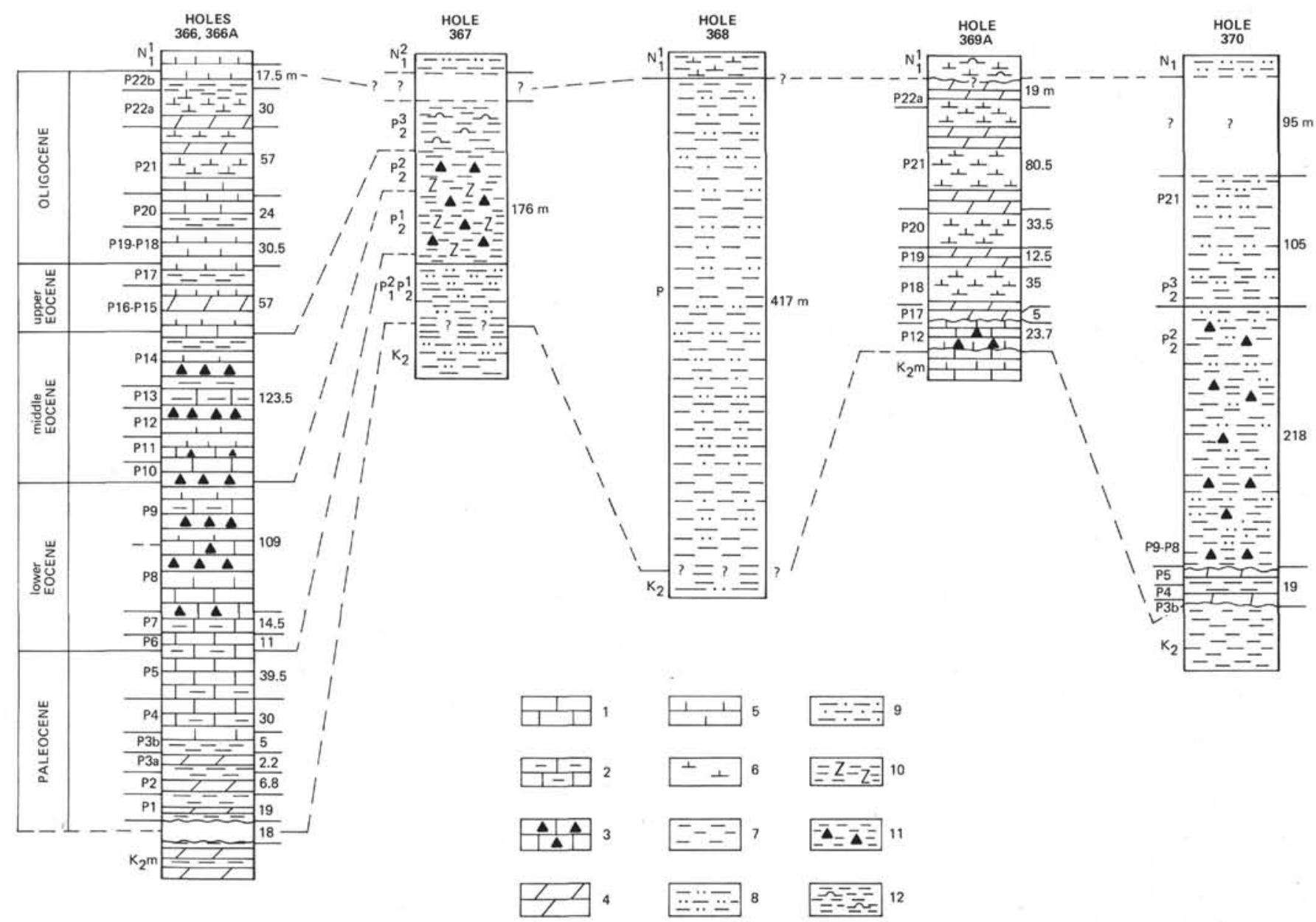

Figure 2. Correlation of Paleogene deposits penetrated by Holes 366, 366 A, 367, 368, 369A, and 370. Lithological symbols: 1 - limestones, 2 - clayey limestones, 3 - siliceous limestones and porcellanites, 4 - marls, 5 - nanno chalk, 6 - nanno oozes, 7 - clays, 8 - silty clays, 9 - sandy clays, 10 - zeolitic clays, 11 - siliceous clays and clays with cherts, 12 - radiolarian clays. Stratigraphic symbols: $K_{2}$ - Upper Cretaceous, $K_{2} m$-Maestrichtian, $P$-Paleogene, $P_{1}^{2}$ - upper Paleocene, $P_{2}^{I}$ - lower Eocene, $P_{2}^{2}$ - middle Eocene, $P_{2}^{3}$ - upper Eocene, $N_{1}^{1}$ - lower Miocene, $N_{1}^{2}$ - middle Miocene; foraminiferal zones of Paleogene: $P 1$ Globorotalia trinidadensis, P2 - Acarinina uncinata, P3A - Globorotalia angulata, P3b - Globorotalia pusilla, P4 - Globorotalia pseudomenardii, P5 - Globorotalia velascoensis, P6 - Globorotalia formosa, P8 - Globorotalia aragonensis, P9 - Globorotalia palmerae, P10 - Hantkenina aragonensis, P11 - Globigerapsis kugleri, P12 - Globorotalia lehneri, P13 - Orbulinoides beckmanni, P14 - Truncorotaloides rohri, P15 - Globigerapsis semiinvoluta, P16 - Globorotalia cerroazulensis, P17 - Globorotalia "centralis" - Globigerina turritilina, P18 - Globigerina tapuriensis, P19 - Globigerina sellii, P20 - Globigerina ampliapertura, P21 - Globorotalia opima, P22A - Globigerina ciperoensis, P22b-Globorotalia kugleri s. str. Thickness is given in meters. When boundaries between adjacent zones are indistinct thickness is given for stratigraphic subdivisions of the higher rank.

366A, 369A), Globorotalia kugleri s. str. (Hole 366A) zones.

Thus, only two zones of the lowermost part of the Danian stage have not been established due to an incomplete set of samples. Also, the Hantkenina aragonensis and Globigerapsis kugleri zones in the middle Eocene, as well as the Globigerapsis semiinvoluta and Globorotalia cerroazulensis zones in the upper Eocene, cannot be differentiated one from another owing to the poorly preserved microfauna.

Some of the above zones in the stratigraphic schemes of other authors are given under the other names, but it does not change their essence. Consequently, the study of stratigraphy of Paleogene calcareous deposits in
Holes $366,366 \mathrm{~A}, 369 \mathrm{~A}$, and 370 shows the importance of planktonic foraminifers for the subdivision of sediments of this age, and the unity of the zonal scale within the tropical and subtropical area.

Previously the zonal stratigraphy of the Paleogene of northwest Africa and the adjacent area of the Atlantic Ocean was not studied thoroughly. On the African continent the Paleogene Ocean formed small gulfs with shallow-water sediments. They usually abounded in benthic organisms and plankton occurred sporadically. Therefore, the zonal subdivision of the Paleocene and Eocene (according to planktonic foraminifers) of the western part of Morocco (Aubert, 1962), the Spanish Sahara (Colom, 1965), and Senegal (Castelain, 1965; 
TABLE 2

Distribution of Planktonic Foraminifers in Paleogene Deposits penetrated by Holes 366, 366A, 367, 369, and 370

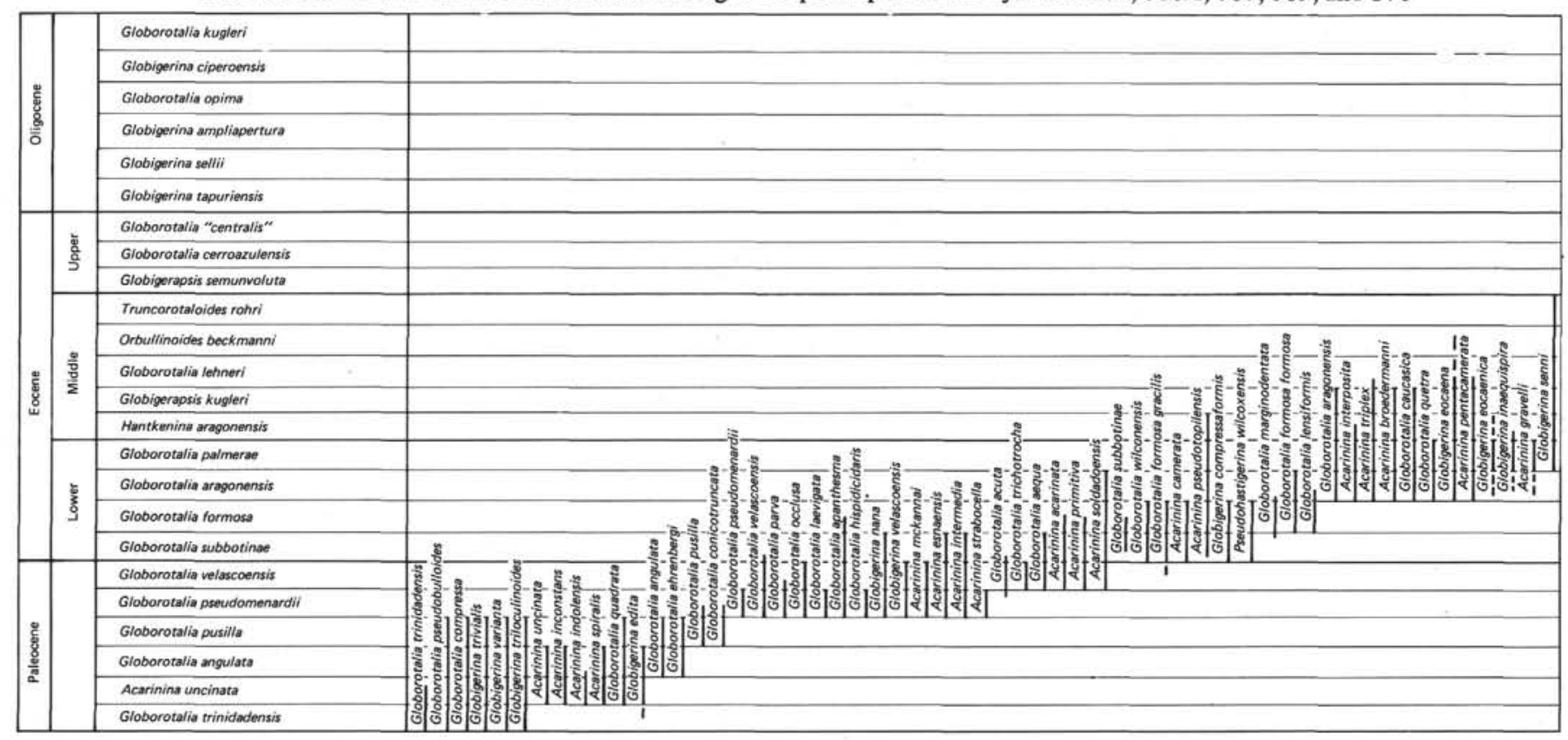

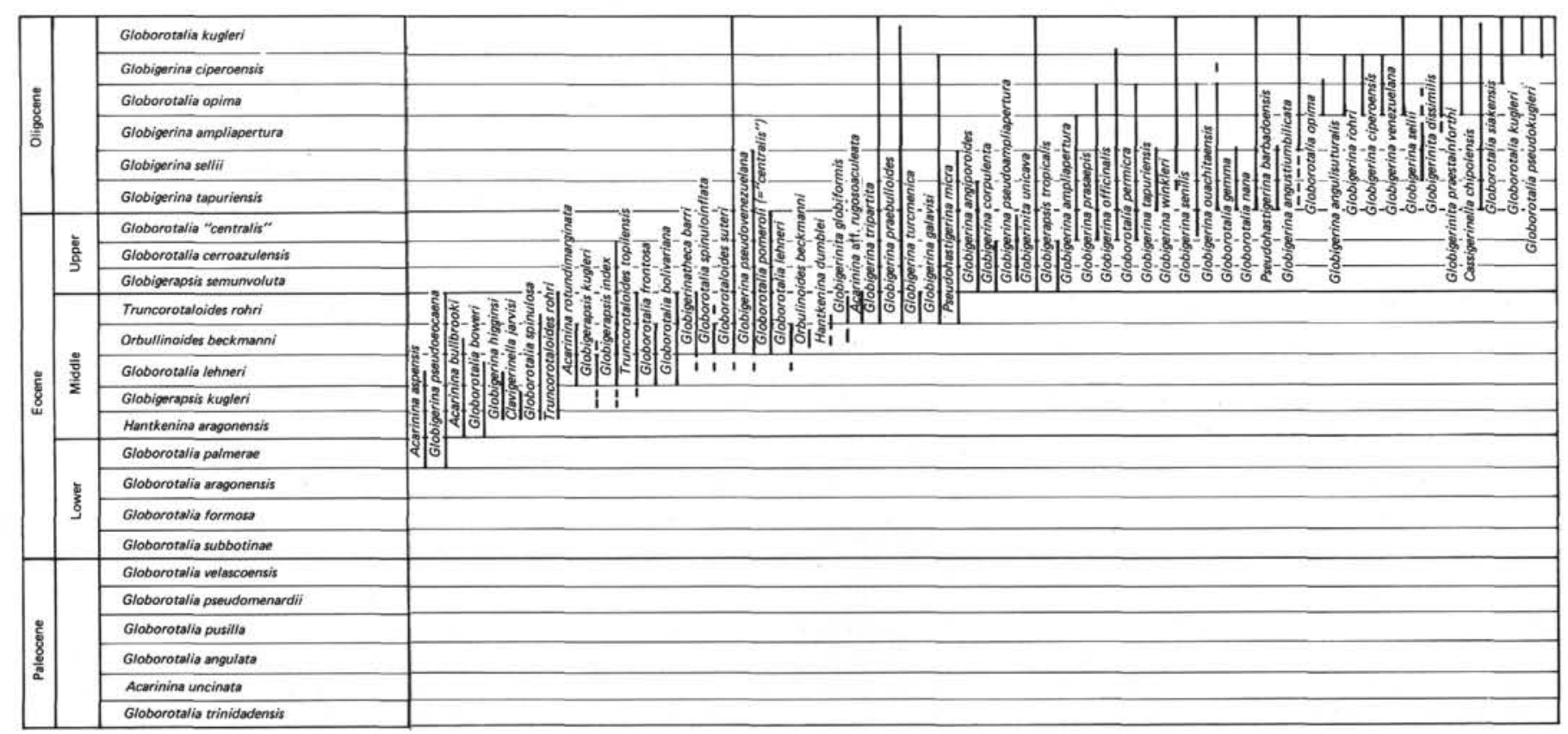


Marie, 1965; Monciardini, 1966) is not detailed. The information based on Oligocene plankton is poor. On the other hand, DSDP Holes 12, 13, 135, 136, 138, and 140 are associated with abyssal regions of the Atlantic Ocean-the Morocco and Canary basins, the foot of Cape Verde and Sierra Leone Rises (Peterson, Edgar, et al., 1970; Maxwell, von Herzen, et al., 1970; Hayes, Pimm, et al., 1972). These holes penetrated the Paleogene, mainly in the facies of pelagic brown clays in which planktonic foraminifers are very poor or absent. As result, the stratigraphic studies of Leg 41 significantly extend our knowledge about stratigraphy of the Paleogene of the Atlantic Ocean off western Africa.

At the same time, these studies showed the difficulties in using the zonal scale for subdivision of a certain section of Paleogene deposits. Thus, in Holes 366 and 366A only the deposits of the middle and upper parts of Oligocene (the Globigerina ampliaperturaGloborotalia kugleri s. str. zones) are characterized by abundant planktonic foraminifers of perfect preservation, and their specific composition is peculiar to the entire tropical and subtropical area. On the contrary, the sediments of Paleocene-the lower part of Oligocene age frequently contain impoverished assemblages of poorly preserved planktonic foraminifers. A number of species representative of the Paleogene of the tropical and subtropical area is absent (almost all species of Hantkenina and Cribrohantkenina, Globorotalia pasionensis, G. acutispira, G. palmerae, G. pseudomayeri, G. renzi, G. cerroazulensis, G. cocoaensis, G. cunialensis, Acarinina multiloculata, Globigerapsis semiinvoluta, Globigerina turritilina, Clavigerinella akersi, Globigerinita echinata), or is presented by single specimens (Globorotalia trinidadensis, G. lehneri, Globigerina higginsi, G. sellii, Pseudohastigerina wilcoxensis, Ps. micra, Clavigerinella jarvisi, Orbulinoides beckmanni). Paleogene sediments of Holes 366 and 366 A are certain to have been formed under conditions of the tropical climatic belt. This can be evidenced by the assemblages of planktonic foraminifers in which globorotaliids are strongly predominant over globigerinids. But among globorotaliids, representatives of Acarinina prevail, whereas species of Globorotalia are in subordinate amounts. As result, the Paleocene and Eocene assemblages of planktonic foraminifers of the Sierra Leone Rise are similar to a temperate-subtropical microfauna from synchronous sediments of the Crimea and North Caucasus.

Paleoecological patterns of the Paleocene and Eocene microfauna of the Sierra Leone Rise can be hardly explained now. We can assume primary impoverishment of planktonic foraminifers (in relation to cold-water currents). The secondary impoverishment of paleocoenoses due to selective dissolution of planktonic foraminifers is possible as well. In this case one can imagine either considerably greater depths of the ocean (the present-day depth being $2860 \mathrm{~m}$ ), or a higher position of the carbonate compensation depth which did not alter throughout the Paleocene-Eocene time. Neither of these explanations can be regarded as satisfactory. This problem is likely to be solved after thorough additional regional stratigraphic studies of this area of the Atlantic Ocean. In Hole 369A (depth of the ocean $1760 \mathrm{~m}$ ) planktonic foraminifers are already perfectly well preserved, and have a diverse specific composition.

The geological history of the Atlantic Ocean near the northwestern coast of Africa throughout Paleogene time can be reconstructed in only very general outlines, because the number of the holes is limited.

On the Sierra Leone Rise the process of sedimentation at the Cretaceous-Paleogene boundary appears to be continuous. In any case the Danian stage (the Globorotalia trinidadensis Zone) and the Acarinina uncinata Zone are very well developed. Carbonate oozes with abundant planktonic foraminifers contain almost no benthic foraminifers, which suggests the pelagic deep-water origin of oozes. If the planktonic foraminifers were affected by selective dissolution, its degree does not differ from that in overlying sediments of Paleocene, Eocene, and lower Oligocene. As to the basal layers of the Danian stage with minute globigerinas, they have not likely been established due to an insufficient number of samples, with sample gaps being up to 18 meters.

Slightly carbonate and noncarbonate clays of the Upper Cretaceous and Paleogene in Holes 367 and 368 are poor in fossil remains (Cape Verde Basin and Rise), and a precise stratigraphic control is impossible. The Cretaceous-Paleogene boundary remains obscure here. Besides, in Hole 367 the Upper Cretaceous is separated from the late Paleocene-early Eocene sediments by a 90-meter uncored interval.

On the continental slope at the Spanish Sahara (Hole 369A) the Paleogene (middle Eocene, the Globorotalia lehneri Zone) is separated from the Upper Cretaceous (late Maestrichtian) by a large gap. There is also a large gap in the Morocco Basin (Hole 370), where the lower Paleocene (the Globorotalia pusilla Zone) occurs directly on the lower Cenomanian. Unfortunately the areal extention of these gaps is not known, and the conditions that caused them, remain open to discussion.

Calcareous sediments of the entire Paleocene sequence are well developed on the Sierra Leone Rise. In the Cape Verde Basin and at the foot of the Cape Verde Rise the Paleocene can be attributed noncarbonate clays with primitive agglutinated foraminifers underlying the lower Eocene. On the continental slope off Spanish Sahara no Paleocene has been recognized; in the Morocco Basin only the upper half is represented by marls and clays (the Globorotalia pusilla-Globorotalia velascoensis zones).

On the Sierra Leone Rise the Eocene and Paleocene are connected by a gradual transition. In the Morocco Basin they are separated by a gap with the omission of two zones (the Globorotalia subbotinae and Globorotalia formosa). In abyssal clay sediments penetrated by Holes 367 and 368, the relation of Paleocene and Eocene remains obscure.

The entire Eocene occurs on the Sierra Leone Rise. In noncarbonate and slightly carbonate clay sediments of the Cape Verde Basin at least all the three subseries of Eocene have been established. The problem of the upper Eocene remains open to question.

An extremely important lithological feature of the lower and middle Eocene is the presence of cherty interbeds and nodules. In their distribution they are 
independent on accompanying sediments being associated with both the calcareous and the clayey sediments. Similar lithological patterns are peculiar to the lower and middle Eocene of North Africa, from Morocco to Egypt and the Near East.

A stratigraphically complete Oligocene section occurs in calcareous oozes on the Sierra Leone Rise and the continental slope off Spanish Sahara. In the Morocco Basin only silty clays of the upper Oligocene have been reliably established (the Globorotalia opima Zone). It is not excluded that in the Cape Verde Basin and the like rise the Oligocene is part of paleontologically barren clays (Hole 368 ) and turbidites (Hole 367).

On the Sierra Leone Rise the Miocene rests conformably on the Oligocene. In fact, the same relation is observed on the continental slope off Spanish Sahara. In the Morocco Basin, in the basin and rise of the Cape Verde Islands the character of relationship between Paleogene and Neogene remains uncertain.

Thus, the process of sedimentation in the Paleogene time on the Sierra Leone Rise was characterized by surprising constancy, and Holes 366 and $366 \mathrm{~A}$ penetrated a quite continuous section of carbonate sediments of this age, 588 meters thick. In the basin and at the rise of the Cape Verde Islands (Holes 367 and 368) the thicknesses of abyssal clay sediments of Paleogene age are rather great $(158 \mathrm{~m}$ and $456 \mathrm{~m}$, respectively). One can assume here, too, a relative continuity of Paleogene sedimentation, but there are no paleontological evidences available. At the foot of the continental slope (Morocco Basin) and on the very slope off Spanish Sahara the Paleogene sections are shortened, stratigraphically incomplete, and with some gaps. All these data are certain to be regarded as the beginning of studying the Paleogene history off the coast of northwest Africa.

\section{PALEONTOLOGICAL PART}

As has already been stated, the preservation of Paleocene and Eocene planktonic foraminifers is not satisfactory, making identification and determination of stratigraphic intervals difficult (Table 2). Therefore, the images accompanied by short comments are given for planktonic foraminifers from Oligocene sediments only.

\section{Globigerina ampliapertura Bolli}

(Plate 2, Figures 1-3)

Globigerina ampliapertura Bolli, 1957, p. 108, pl. 22, fig. 5.

This species is a significant element of the Oligocene microfauna in Holes 366, 366 A, and 369A. The first specimens of this species are sure to appear in the top of the upper Eocene (the Globorotalia "centralis"-Globigerina turritilina Zone). There is a small "gap" between the last specimens of $G$. ampliapertura and the first ones of Globorotalia opima, this being the cause of difficulties of the precise drawing the boundary between the zones with the two given index species.

\section{Globigerina praebulloides Blow}

(Plate 1, Figures 8-10)

Globigerina praebulloides Blow, 1959, p. 180, pl. 8, fig. 47.

It is common for the entire pile of Oligocene deposits. At least two subspecies can be recognized-G. praebulloides praebulloides and $G$. praebulloides occlusa Blow et Banner.

\section{Globigerina ciperoensis Bolli}

(Plate 1, Figures 5-7)

Globigerina ciperoensis Bolli, 1954, p. 1, test-fig. 3-6; 1957, p. 109, pl. 22, fig. 10.
Sporadic questionable specimens of this species were observed in the top of the Globigerina ampliapertura Zone. It is representative of deposits of the Globorotalia opima and Globigerina ciperoensis zones, but by the number of specimens it yields considerably to Globigerina angulisuturalis.

\section{Globigerina prasaepis Blow}

(Plate 2, Figures 4,5)

Globigerina prasaepis Blow, 1969, p. 382, pl. 10, fig. 13; pl. 18, fig. 3-7.

Rare specimens of $G$. prasaepis were found in the top of the upper Eocene (the Globorotalia "centralis"-Globigerina turritilina Zone), Holes 366 and 369A. Typical and numerous specimens of this species characterize the Globigerina tapuriensis-Globigerina ampliapertura zones of Oligocene age. In the Globorotalia opima Zone the species becomes rare.

\section{Globigerina angustiumbilicata Bolli}

(Plate 1, Figures 3,4)

Globigerina angustiumbilicata Bolli, 1957, p. 109, pl. 22, fig. 12,13; p. 164 , pl. 36 , fig. 6 .

It is common in all zones of Oligocene deposits, and appears in the top of the upper Eocene.

\section{Globigerina angulisuturalis Bolli}

(Plate 1, Figures 1,2)

Globigerina angulisuturalis Bolli, 1957, p. 109, pl. 22, fig. 11.

The species is common for the Globorotalia opima Zone. In the deposits of the Globigerina ciperoensis Zone its specimens are abundant, frequently exceeding all other representatives of planktonic foraminifers. In the Globorotalia kugleri s. str. Zone the species was not recognized.

\section{Globigerina galavisi Bermudez \\ (Plate 2, Figures 6-8)}

Globigerina galavisi Bermudez, 1961, p. 1-183, pl. 4, fig. 3 .

The species was found in the Truncorotaloides rohri Zone of the middle Eocene and in all zones of the upper Eocene and Oligocene, the numbers of specimens being usually limited.

\section{Globigerina officinalis Subbotina}

(Plate 4, Figures 1,2)

Globigerina officinalis Subbotina, 1953, p. 78, pl. 11, fig. 1, 2, 5.

A small test with the cross-like arrangement of chambers and the arch-shaped aperture opened into the umbilical area. The scope of this species is frequently understood too generally. The species appears in the Globorotalia "centralis"-Globigerina turritilina Zone of the upper Eocene, is very peculiar to the Oligocene Globigerina tapuriensis-Globigerina ampliapertura zones, and becomes rare in the upper half of Oligocene (the Globorotalia opima and Globigerina ciperoensis zones).

\section{Globigerina rohri Bolli}

(Plate 5, Figures 6-8)

Globigerina rohri Bolli, 1957, p. 109, pl. 23, fig. 1-4.

At present this species is generally considered as a junior synonym of G. tripartita Koch. In deposits of the Globorotalia opima and Globigerina ciperoensis zones (Holes 366A and 369A), however, a species of planktonic foraminifers with a spherical test and three strongly embracing chambers was recognized. It is identical to the image of the species in the paper by Bolli (1957). At the same time, it differs from $G$. tripartita, as well as from $G$. venezuelana and $G$. sellii in their morphological patterns. The interval of stratigraphic distribution of this species is much narrower than in $G$. tripartita. In this paper the species is defined under the name of G. rohri (in Bolli's sense), and the question of its synonymy remains open to discussion.

\section{Globigerina tripartita Koch}

(Plate 3, Figures 1,2)

Globigerina bulloides tripartita Koch, 1926 , p. 746 , test-fig. 21; Globigerina tripartita Blow and Banner, 1962, p. 96, pl. X, fig. A-F.

An almost three-chambered test has an elongate-oval shape and is supplied with a reduced tooth-like flap on the ventral side. The species is characterized by a broad stratigraphic interval-from the Truncorotaloides rohri Zone (middle Eocene) to the top of the 
Oligocene, being presented, however, by a small number of specimens.

\section{Globigerina ouachitaensis Howe and Wallace}

(Plate 1, Figures 11,12; Plate 4, Figures 9-11)

Globigerina ouachitaensis Howe and Wallace, 1932, p. 74, pl. 10, fig. 7.

There are two subspecies within the given species: numerous specimens of $G$. ouachitaensis ouachitaensis occur in all Oligocene zones; $G$. ouachitaensis gnaucki Blow and Banner, characterized by a larger test with subsquared outlines and a large aperture; presented by rare specimens that exist mainly in the Globigerina ampliaperturaGlobigerina ciperoensis zones.

\section{Globigerina senilis Bandy \\ (Plate 4, Figures 6-8)}

Globigerina ouachitaensis senilis Bandy, 1949, p. 121, pl. 22, fig. 5. The species is developed in deposits of the Globigerina tapuriensisGlobigerina ampliapertura zones of the Oligocene. Very rare specimens were recognized in the Globorotalia opima Zone.

\section{Globigerina angiporoides Hornibrook}

(Plate 4, Figures 3-5)

Globigerina angiporoides Hornibrook, 1961, p. 145, text-fig. 3; 1965, p. 834 , fig. 1,2 .

Not numerous specimens of this species were observed in the undifferentiated upper Eocene of the Sierra Leone Rise, the microfauna, however, being poor here. The species ceases existence in the Globigerina tapuriensis Zone of the Oligocene (Hole 369A), where rare specimens of $G$. angiporoides have a typical apertural lip.

\section{Globigerina anguliofficinalis Blow}

(Plate 5, Figures 1-3)

Globigerina anguliofficinalis Blow, 1969, p. 379, pl. 11, fig. 1-5.

The species is characterized by $4-1 / 2$ to 5 -chambered tests with distinct U-shaped intercameral sutures on the umbilical side of the test. It is common in deposits of the Globigerina tapuriensisGlobigerina ampliapertura zones of Oligocene.

\section{Globigerina tapuriensis Blow and Banner}

(Plate 3, Figures 3-5)

Globigerina tripartita tapuriensis Blow and Banner, 1962, p. 97, pl. 10, fig. H-K.

It occurs not very frequently in deposits of the lower part of the Oligocene (the Globigerina tapuriensis and Globigerina sellii zones).

\section{Globigerina sellii (Borsetti)}

(Plate 3, Figures 6,7)

Globoquadrina sellii Borsetti, 1959, p. 209, pl. 1, fig. 3.

In Hole $369 \mathrm{~A}$ the rare specimens of this species characterize deposits of the Globigerina sellii and Globigerina ampliapertura zones; in the Globorotalia opima Zone they are quite sporadic (Oligocene). In Hole $366 \mathrm{~A}$ small poorly preserved specimens of $G$. sellii were recognized in the Globorotalia opima Zone only. No specimens of this species have been found in underlying Oligocene deposits of this hole. This inhibits the establishing the Globigerina sellii Zone.

\section{Globigerinita dissimilis (Cushman and Bermudez)}

(Plate 7, Figures 1, 2)

Globigerina dissimilis Cushman and Bermudez, 1937, p. 25, pl. 3, fig. 4-6.

Typical representatives of this species are developed in the upper part of Oligocene (the Globorotalia opima, Globigerina ciperoensis, Globorotalia kugleri s. str. zones).

\section{Globigerinita unicava (Bolli, Loeblich, and Tappan)}

(Plate 7, Figures 4-6)

Catapsydrax unicavus Bolli, Loeblich and Tappan, 1957, p. 37, pl. 7, fig. 9.

The species occurs frequently in deposits of all Oligocene zones. A few specimens also occurred in the upper Eocene of Hole 366.

\section{Globigerinita stainforthi praestainforthi Blow}

(Plate 7, Figures 1, 2)

Globigerinita stainforthi praestainforthi Blow, 1969, p. 383, pl. 25, fig. 3-5.

This is a common element of planktonic foraminiferal assemblages in late Oligocene sediments (the Globorotalia opimaGloborotalia kugleri s. str. zones).

\section{Cassigerinella chipolensis (Cushman and Ponton)}

(Plate 8, Figures 7, 8)

Cassidulina chipolensis Cushman and Ponton, 1932, p. 98, pl. 15, fig. 2 .

The species is observed in deposits of all Oligocene zones, though a number of specimens in each of samples studied have undergone strong changes.

\section{Globorotaloides suteri Bolli}

(Plate 7, Figures 7-9)

Globorotaloides suteri Bolli, 1957, p. 117, pl. 27, fig. 9-13; p. 166, pl. 37 , fig. 10-12.

The species appears in the Truncorotaloides rohri Zone of middle Eocene and is common for upper Eocene and Oligocene deposits.

\section{Pseudohastigerina barbadoensis Blow (Plate 8, Figures 1-3)}

Pseudohastigerina barbadoensis Blow, 1969, p. 409, pl. 53, fig. 7-9; pl. 54, fig. 1-3.

Rather numerous specimens of this species are confined to the lower part of Oligocene (the Globigerina tapuriensis and Globigerina sellii zones).

\section{Pseudohastigerina micra (Cole) \\ (Plate 8, Figures 4-6)}

Nonion micrus Cole, 1927, p. 22, pl. 5, fig. 12.

The species is known to be characterized by a wide interval of the stratigraphic distribution (middle Eocene-lower Oligocene). In our material, however, it was seldom recognized-the Truncorotaloides rohri Zone of middle Eocene (Hole 366) and the Globigerina tapuriensis Zone of lower Oligocene (Hole 369A). Oligocene specimens of this species are tiny, and differ from Ps. barbadoensis in a smooth surface of the test, thin septal sutures and absence of distinct granulation in the umbilical area.

\section{Globorotalia opima Bolli}

(Plate 6, Figures 7-9)

Globorotalia opima Bolli, 1957, p. 117, pl. 2b, fig. 1,2.

Numerous specimens of this species characterize the Globorotalia opima Zone only. Specimens of big size, but having only four chambers in the last whorl also have been attributed to G. opima. In Oligocene underlying sediments the species was not recognized.

\section{Globorotalia nana Bolli}

(Plate 6, Figures 10,11)

Globorotalia opima nana Bolli, 1957, p. 118, pl. 28, fig. 3 .

This variety is regarded by us as an independent species differing from $G$. opima in a small, four-chambered test with a very close arrangement of chambers. The stratigraphic interval of $G$. nana embraces the entire Oligocene-from the Globigerina tapuriensis Zone (Hole 369A) to the Globorotalia kugleri s. str. Zone (Hole $366 \mathrm{~A})$.

\section{Globorotalia permicra Blow and Banner}

(Plate 6, Figures 12-14)

Globorotalia permicra Blow and Banner, 1962, p. 120, pl. 12, fig. N-P,

The species appears in the top of upper Eocene (the Globorotalia "centralis"-Globigerina turritilina Zone) and is widespread in the lower half of Oligocene (the Globigerina tapuriensis-Globigerina ampliapertura zones). Rare specimens of $G$. permicra have been established in basal layers of the Globorotalia opima Zone (Hole 369A). 


\section{Globorotalia gemma Jenkins}

(Plate 5, Figures 9-11)

Globorotalia gemma Jenkins, 1965, p. 1115, fig. 11, No. 97-103. It occurs frequently in deposits of the lower part of Oligocene (the Globigerina tapuriensis and Globigerina sellii zones); rare specimens were found in the Globigerina ampliapertura Zone.

\section{Globorotalia (?) brevispira (Subbotina)}

(Plate 5, Figures 4,5)

Globigerina brevispira Subbotina, 1960, p. 56, pl. 11, fig. 4-6.

A small test of this species with 4 to $4-1 / 2$ chambers in the last whorl is characterized by the umbilical-extraumbilical position of the aperture. Belonging of $G$. brevispira to the genus Globigerina or Globorotalia is still unknown.

The species had been described by Subbotina from the late Oligocene of the northeastern Carpathians, but in the Leg 41 material it was also found in the older sediments of Oligocene (the Globigerina ampliapertura Zone-the Globorotalia opima Zone).

\section{Globorotalia kugleri Bolli}

(Plate 6, Figures 1-3)

Globorotalia kugleri Bolli, 1957, p. 118, pl. 28, fig. 5,6.

Abundant in the sediments of the uppermost Oligocene (the Globorotalia kugleri Zone s. str.), Hole 366A.

\section{Globorotalia pseudokugleri Blow}

(Plate 6, Figures 4-6)

Globorotalia (Turborotalia) pseudokugleri Blow, 1969, p. 391, pl. 10, fig. $4-6$, pl. 39 , fig. 5,6

This species clearly differs from $G$. kugleri in having almost symmetrical oval test from the peripheral view, with rounded (not subacute) peripheral margin. Chambers on the spiral side are inflated, rounded. Intercameral sutures are straight both on spiral and umbilical sides.

This species appears in the very top of the Globigerina ciperoensis Zone but is much more typical for the Globorotalia kugleri Zone s. str.

\section{Chiloguembelina ex gr. cubensis (Palmer)}

(Plate 8, Figures 9,10)

Small representatives of Chiloguembelina, likely attributed to some species of this genus, are common for deposits of the Oligocene: Globigerina tapuriensis-Globorotalia opima zones.

\section{OBSERVATIONS ON THE ULTRASTRUCTURES}

\section{General Remarks}

In the course of scanning electron microscope work we took micrographs of the ultrastructure of the different tests. For a convenient comparison, the magnifications given in the plates are constant $\times 1000$.

Several different ultrastructures had been recognized within species and specimens, especially there are often differences between the umbilical and spiral sides. For comparisons only those ultrastructures should be used belonging to equivalent parts of the tests. The last chamber of a test often shows peculiarities, sometimes bearing atavistic, sometimes progressive, features. Normally the ultrastructure of the last chamber has been used as being representative for the total specimen. This is because planktonic foraminifers overcrust previous chambers by additional calcite material and hide primary ultrastructural specialities.

The scanning microscope technique permits examination of additional specialities of the test, which may be useful for the paleontologic systematics. Using the ultrastructures of recent specimens for instance Bé (1967) differed between spinose Globigerinidae and nonspinose Globorotaliidae, etc. In comparably old faunas the various processes of dissolution, over- crusting, and diagenesis have to be taken into consideration in using this concept. Therefore, if spines have not been recorded for a species, an ancient spinosity cannot be excluded. But on the contrary, a recorded spinosity, at least by the observation of rests of spine bases or spine pits, should be tested as a tool for classification. Porosity as a part of the ultrastructural features has been treated as being dependent on ecological conditions (see Frerichs et al., 1972). Influences by diagenesis cannot be excluded (see Pflaumann, 1971). However, this reflects only details in a general ultrastructural type. In taxonomy of the ultrastructures we followed mainly Collen and Vella (1973).

\section{Spinose Ultrastructures}

The general outline of this ultrastructural type is given by a more or less granular flat surface, penetrated by almost circular pores with moderate flanges in a regular distribution pattern. Somewhat more irregularly distributed are pustules on the interpore areas, sometimes showing holes, and therefore being interpreted as spine bases. This type of ultrastructure is characteristic for Globigerina and is seen in Globigerina anguliofficinalis (Plate 5, Figures 1b,3b), G. angulisuturalis (Plate 1, Figure 1c), G. angustiumbilicata (Plate 1 , Figure $3 \mathrm{~b}$ ), G. ciperoensis (Plate 1, Figure 5b), G. ouachitaensis ouachitaensis (Plate 4, Figure 11b), G. praebulloides (Plate 1, Figure 10b). G. ouachitaensis gnaucki (Plate 1, Figure 11b) belongs to the same group, but has a slightly smoother surface between the pores and spine basis. The spiral side of the last chamber of G. ampliapertura (Plate 2, Figure 2b) shows some affinities to that group, but the pustules are very low and perforations or spine rests are barely visible. Globorotalia (?) brevispira (Plate 5, Figures 4b,5) shows distinctly developed spine pits on the spiral side, while on the umbilical side the penetrations on the divides are attributed to spine holes, only with some doubts. Therefore, using the spinose ultrastructure as the deciding feature this species should be reincorporated to the genus Globigerina. The features of the aperture, however, are tending to Globorotalia, so we tentatively attribute this species to that genus.

\section{Cancellate Ultrastructures}

Common features of this type are a high porosity and a thick wall. The well-rounded pores are surrounded by relatively narrow divides with steep flanges. The divides are connected forming a well-finished nearly regular polygonal net. At the junctions the divides are often elevated forming pseudospines. Rounded divides with a smoothened microcrystalline surface have been observed in Globigerina galavisi (Plate 2, Figure 6b), $G$. prasaepsis (Plate 2, Figure 4c), G. rohri (Plate 5, Figure 6b), G. sellii (Plate 3, Figure 6c), G. tapuriensis (Plate 3, Figures 4b,5), G. tripartita (Plate 3, Figure 2b). Somewhat coarser are the crystals in Globigerina senilis (Plate 4, Figure 6b), G. angiporoides (Plate 4, Figure $5 \mathrm{~b})$, Globorotalia kugleri (Plate 6, Figures 1b, 3b), G. pseudokugleri (Plate 6, Figures $4 \mathrm{~b}, 6 \mathrm{~b}$ ), and on the umbilical side of Globorotalia nana (Plate 6, Figure $10 \mathrm{~b})$. Divides with sharpened summits are given in Globigerina officinalis (Plate 4, Figure 2c), G. aff. senilis (Plate 4, Figure 8b). 
To the cancellate ultrastructural type are attributed also Globigerinita stainforthi praestainforthi (Plate 7, Figure 1d), G. dissimilis (Plate 7, Figure 3c), G. unicava (Plate 7, Figures 4b, 6b), Globorotaloides suteri (Plate 7, Figures $7 b, 9 b)$. Here the flanges are not as steep in the above mentioned species, sometimes showing "terraces," giving the impression that the divides are offset on an even primary wall. The bullae of Globorotaloides suteri (Plate 7, Figure 9c) and Globigerinita unicava (Plate 7, Figure 6c) show only reduced pore diameters, but fit by their ultrastructures to the normal chambers. In Globigerinita dissimilis the bulla (Plate 7, Figure 3d) has slit-like to rounded pores, which are distinctly smaller and at narrower distances than that of the normal chambers.

Globorotalia opima (Plate 6, Figure 9b), G. nana (Plate 6, Figure 10b), and G. permicra (Plate 6, Figures $12 \mathrm{~b}, 14 \mathrm{~b})$ are attributed to the cancellate type, too, though they differ in that the pores are positioned in the center of flat-bottomed pore pits from which the surrounding divides rise abruptly with steep flanges.

In nearly all specimens with a cancellate ultrastructure there are raised edges of the divides forming pseudospines in the umbilical region and near the aperture.

\section{Perforated-Pustulose Ultrastructures}

The ultrastructure of Globorotalia gemma (Plate 5, Figure $11 \mathrm{~b}$ ) is characterized by a surface, which is penetrated by numerous perforations of different sizes and forms (diameters 0.2 to $0.5 \mu \mathrm{m}$, sometimes elongate to $1.5 \mu \mathrm{m}$ ) and is covered by small pustules.

In Chiloguembelina ex gr. cubensis the perforations are more regularly distributed and larger in diameter (about $0.5 \mu \mathrm{m}$ ). The pustules are strongly elevated, forming pseudospines near the aperture (Plate 8, Figure $9 \mathrm{~b})$ while on the earlier chambers they are united to rows in the direction of the longest axis of the test (Plate 8 , Figure 10b).

Pseudohastigerina micra (Plate 8, Figure 4b) has a very smooth microcrystalline surface with irregularly distributed perforations of different sizes $(0.2-0.5 \mu \mathrm{m}$ in diameter). Pustules are rare, but there are knob-like elevations observed mainly in the peripheral region.

Pseudohastigerina barbadoensis (Plate 8, Figure 1b) is more coarsely finished, there are pores of up to $2 \mu \mathrm{m}$ in diameter, some pustules forming pseudospines mainly in the region of the intercameral sutures, and big knobs are covering the flanges of the test.

Cassigerinella chipolensis (Plate 8, Figure 7b) has a somewhat rough surface with small $(0.5-1 \mu \mathrm{m}$ in diameter) pores and wide distances between them. The rough surface is given by knob-like elevations of the surface, which have the same ultrastructure as the normal wall, so being different to the pustules observed in another specimen (Plate 8, Figure 8b), which are clearly offset on the perforated surface and which are penetrated by holes of about $1 \mu \mathrm{m}$ in diameters. It is up to further investigations, if those pustules have to be interpreted as spine basis or as megapores surrounded by a collar. They are concentrated at the peripheral parts of the chambers.

\section{ACKNOWLEDGMENTS}

The investigations of U. Pflaumann were supported by the Deutsche Forschungsgemeinschaft.

\section{REFERENCES}

Aubert, J., 1962. Les Globorotalia de la région Prerifaine (Maroc septentrional): Notes Serv. Géol. Maroc, v. 21, p. 156.

Bé, A.W.H., 1967. Foraminifera families: Globigerinidae and Globorotaliidae. Fiches d'Identification de Zooplankton, Cons. perm. internat. explor. de la mer: Charlottenlund slot. Zooplankton Sheet 108.

Bolli, H.M., 1957. Planktonic Foraminifera from the Oligocene-Miocene Cipero and Lengua formations of Trinidad, B.W.I.: U.S.Nat . Mus. Bull., p. 215.

Castelain, J., 1965. Aperçu stratigraphique et micropaléontologique du bassin du Sénégal. Historique de la découverte paléontologique: Mém. Bur. Rech. Géol. Min., France, p. 32.

Collen, J.D., Vella, P., 1973. Pliocene planktonic foraminifera, Southern North Island, New Zealand: J. Foram. Res., v. 3, n. 1.

Colom, G., 1965. Micropaleontologia del Sahara espanol: Estud. Geol., v. 21, p. 1-4.

Frerichs, W.E., Heiman, M.E., Borgman, L.E., Bé A.W.H., 1972. Latitudinal variations in planktonic foraminiferal test porosity: part 1. Optical studies: J. Foram. Res., v. 2, p. 1 .

Hayes, D.E., Pimm, A.C., et al., 1972. Initial Reports of the Deep Sea Drilling Project, Volume 14: Washington (U.S. Government Printing Office).

Marie, P., 1965. Sur l'âge des phosphates de chaux de LamLam (région de Thies, Sénégal): Mém. Bur. Rech. Géol. Min., France p. 32.

Maxwell, A., Von Herzen, R., et al., 1970. Initial Reports of the Deep Sea Drilling Project, Volume 3: Washington (U.S. Government Printing Office).

Monciardini, Ch., 1966. La sédimentation Eocène au Sénégal: Mém. Bur. Rech. Géol. Min. France, p. 43.

Peterson, M., Edgar, N., et al., 1970. Initial Reports of the Deep Sea Drilling Project, Volume 2: Washington (U.S. Government Printing Office).

Pflaumann, U., 1971. Porosităten von Plankton-Foraminiferen als Klimaanzeiger?: "Meteor"-Forsch.-Ergebn., C, no. 7 . 



\section{PLATE 1}

Figures 1, 2 Globigerina angulisuturalis Bolli.

Sample 369A-19, CC, Oligocene.

1a. Spiral view, $\times 150$.

1b. Peripheral view, $\times 150$.

1c. Ultrastructure of the spiral side of the last chamber, $\times 1000$.

2. Umbilical view, $\times 150$.

Figures 3,4 Globigerina angustiumbilicata Bolli.

Sample 369A-17, CC, Oligocene.

3a. Spiral view, $\times 150$.

$3 \mathrm{~b}$. Ultrastructure of the spiral side of the last chamber, $\times 1000$.

4. Umbilical view, $\times 150$.

Figures 5-7 Globigerina ciperoensis Bolli.

Sample 369A-15, CC, Oligocene.

5a. Spiral view, $\times 150$.

$5 \mathrm{~b}$. Ultrastructure of the spiral side of the last chamber, $\times 1000$.

6. Peripheral view, $\times 150$.

7. Umbilical view, $\times 150$.

Figures 8-10 Globigerina praebulloides Blow.

Sample 369A-16, CC, Oligocene.

8. Umbilical view, $\times 150$.

9. Spiral view, $\times 150$.

10a. Umbilical view, $\times 150$.

10b. Ultrastructure of the umbilical side of the last chamber, $\times 1000$.

Figures 11,12 Globigerina ouachitaensis gnaucki Blow and Banner.

Sample 369A-16, CC, Oligocene.

11a. Umbilical view, $\times 150$.

11b. Ultrastructure of the umbilical side of the last chamber, $\times 1000$.

12. Spiral view, $\times 150$. 


\section{PLATE 1}

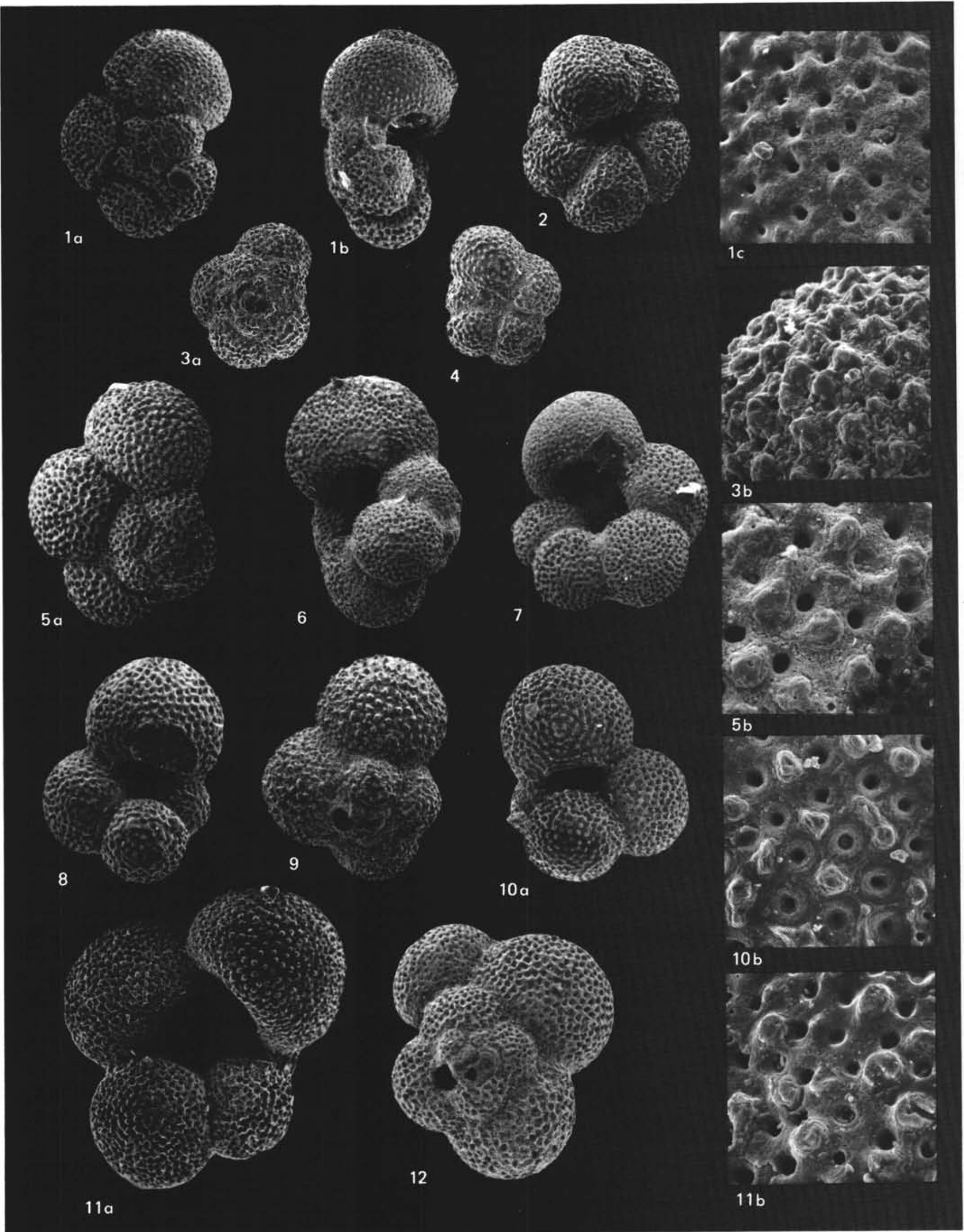




\section{PLATE 2}

Figures 1-3 Globigerina ampliapertura Bolli.

Sample 369A-30, CC, Oligocene.

1. Umbilical view, $\times 150$.

2. Peripheral view, $\times 150$.

3a. Spiral view, $\times 150$.

$3 \mathrm{~b}$. Ultrastructure of the spiral side of the last chamber, $\times 1000$.

Figures 4, $5 \quad$ Globigerina prasaepis Blow.

Sample 369A-31, CC, Oligocene.

4a. Spiral view, $\times 150$.

4b. Peripheral view, $\times 150$.

4c. Ultrastructure of the spiral side of the last chamber, $\times 1000$.

5. Umbilical view, $\times 150$.

Figures 6-8 Globigerina galavisi Bermudez.

Sample 369A-28-3, 71-73 cm, Oligocene.

6a. Spiral view, $\times 150$.

6b. Ultrastructure of the spiral side of the last chamber, $\times 1000$.

7. Peripheral view, $\times 150$.

8. Umbilical view, $\times 150$. 
PLATE 2
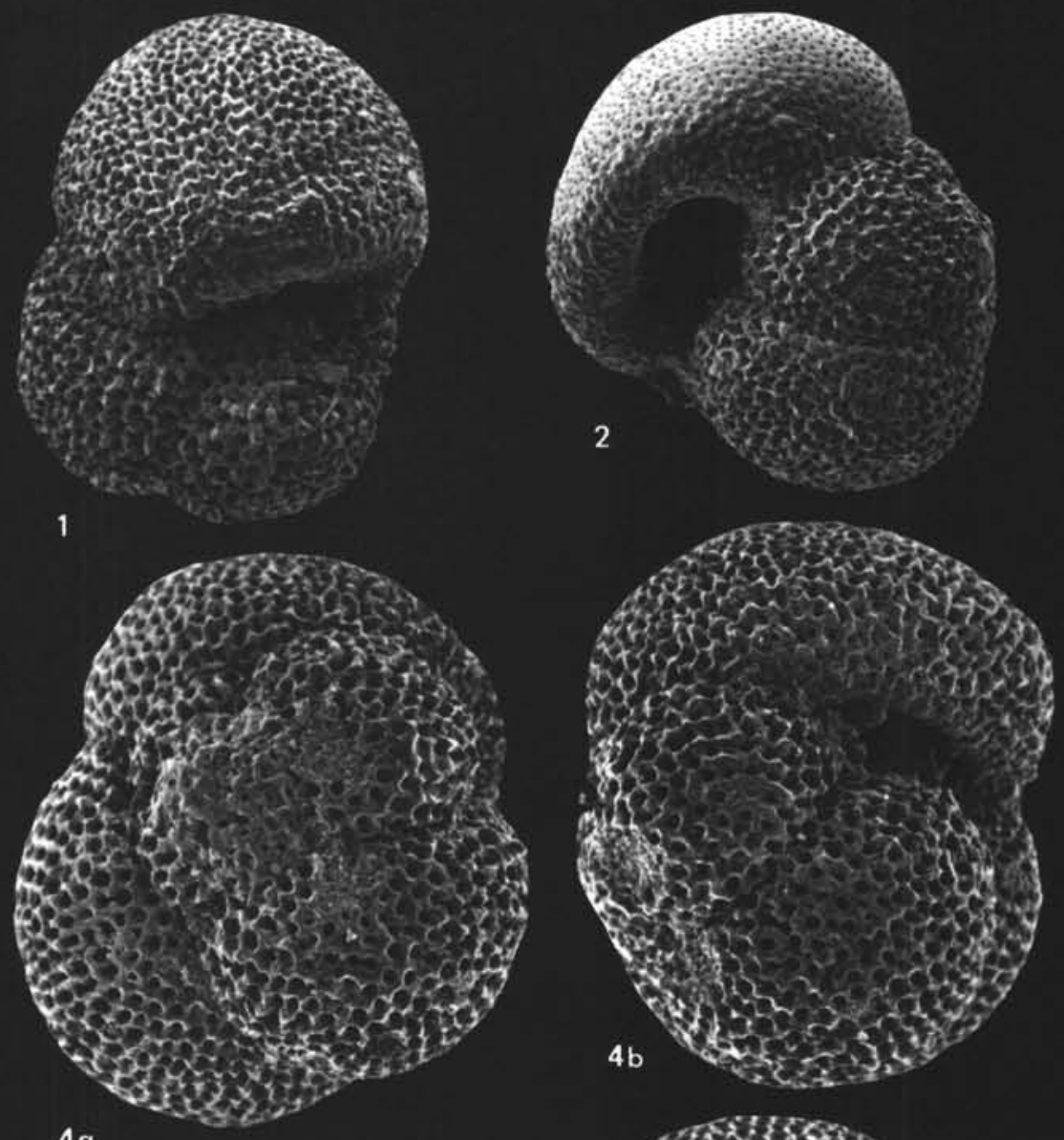

$4 a$
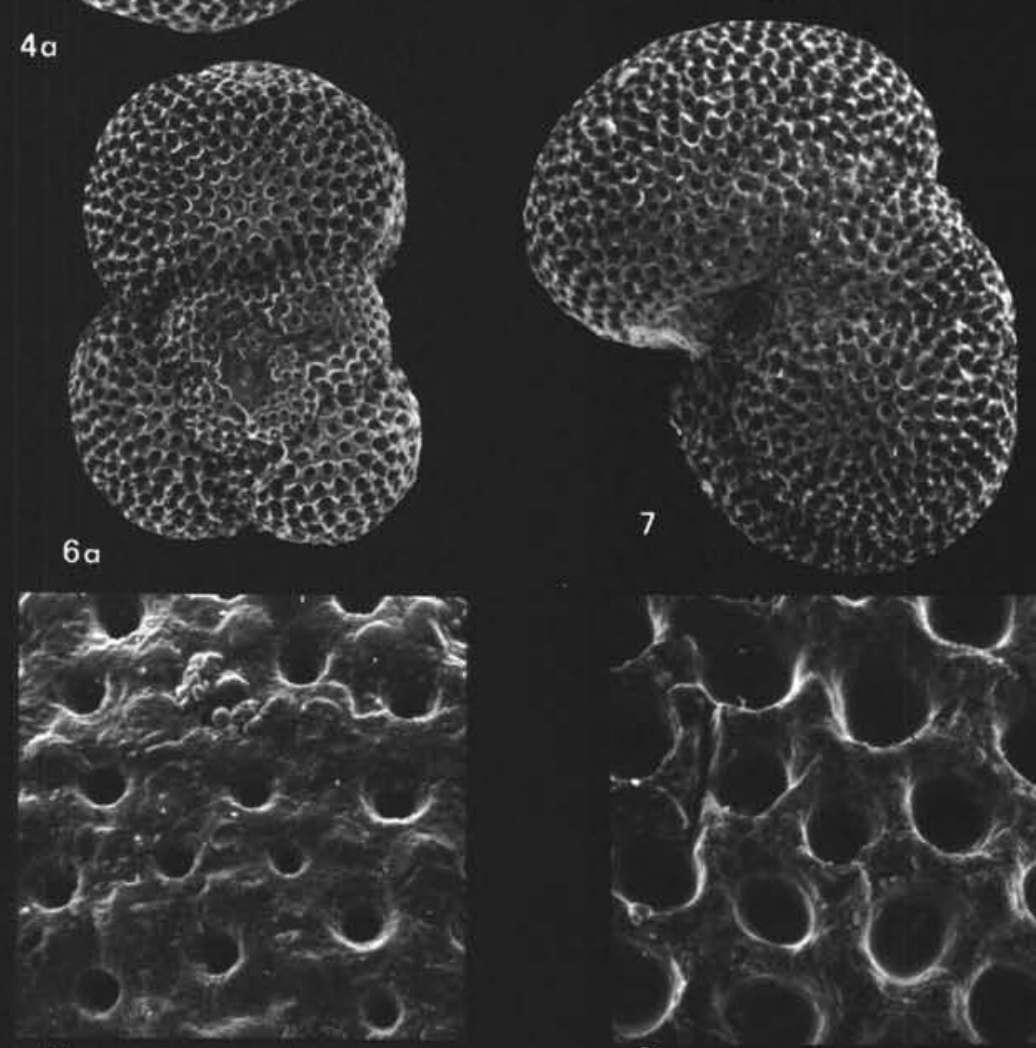

$3 b$
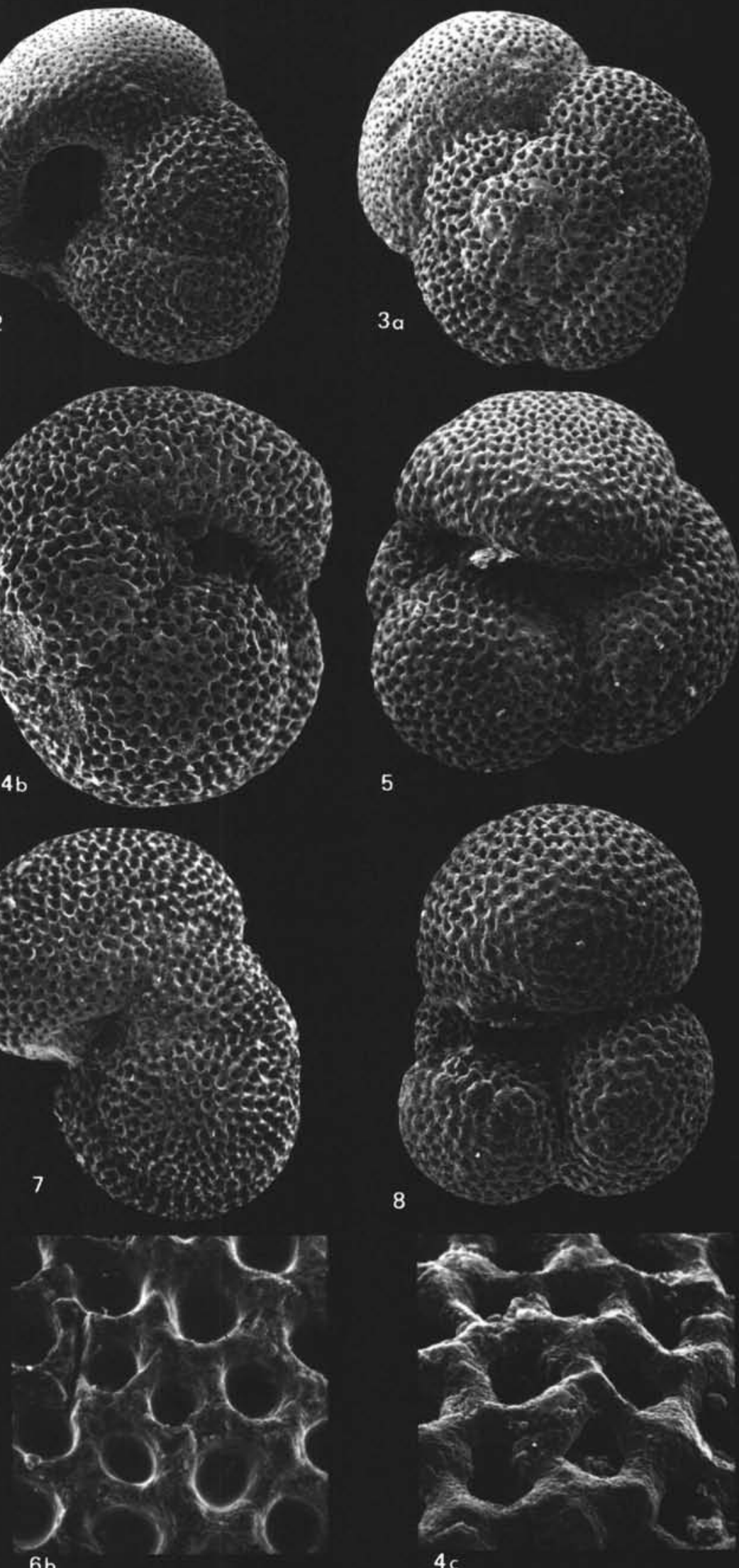

5
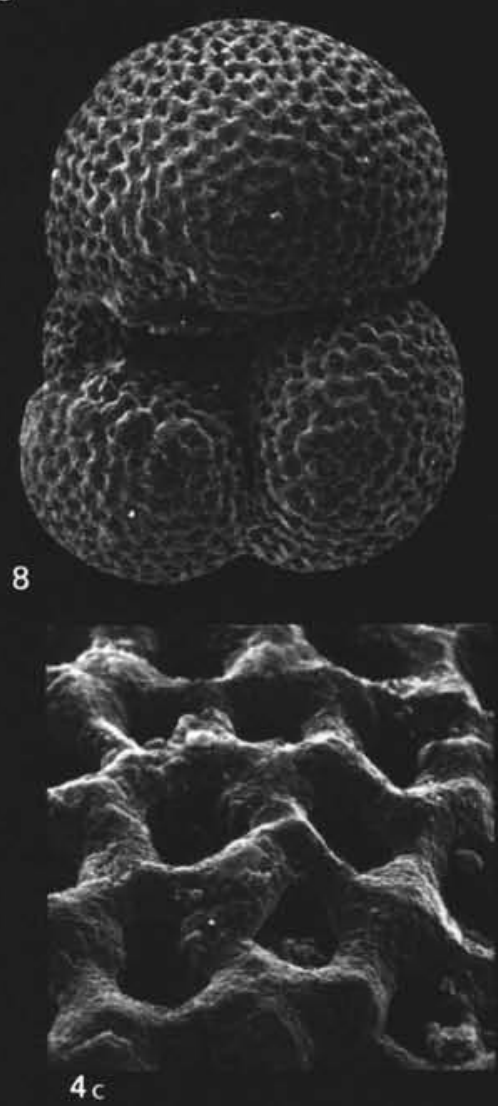


\section{PLATE 3}

Figures 1,2 Globigerina tripartita Koch.

Sample 369A-30,CC, Oligocene.

1a. Umbilical view, $\times 150$.

1b. Peripheral view, $\times 150$.

2a. Spiral view, $\times 150$.

2b. Ultrastructure of the spiral side of the last chamber, $\times 1000$.

Figure 3 Globigerina tapuriensis Blow and Banner.

Sample 369A-30-1, 71-73 cm, Oligocene.

3a. Umbilical view, $\times 150$.

3 b. Peripheral view, $\times 150$.

Figures 4, $5 \quad$ Globigerina tapuriensis Blow and Banner.

Sample 369A-30,CC, Oligocene.

4a. Spiral view, $\times 150$.

4b. Ultrastructure of the spiral side of the last chamber, $\times 1000$.

5. Ultrastructure of the umbilical side of the last chamber, $\times 1000$.

Figures 6,7 Globigerina sellii (Borsetti).

Sample 369A-28-2, 61-63 cm, Oligocene.

6a. Umbilical view, $\times 150$.

6b. Peripheral view, $\times 150$.

6c. Ultrastructure of the umbilical side of the last chamber, $\times 1000$.

7. Spiral view, $\times 150$. 

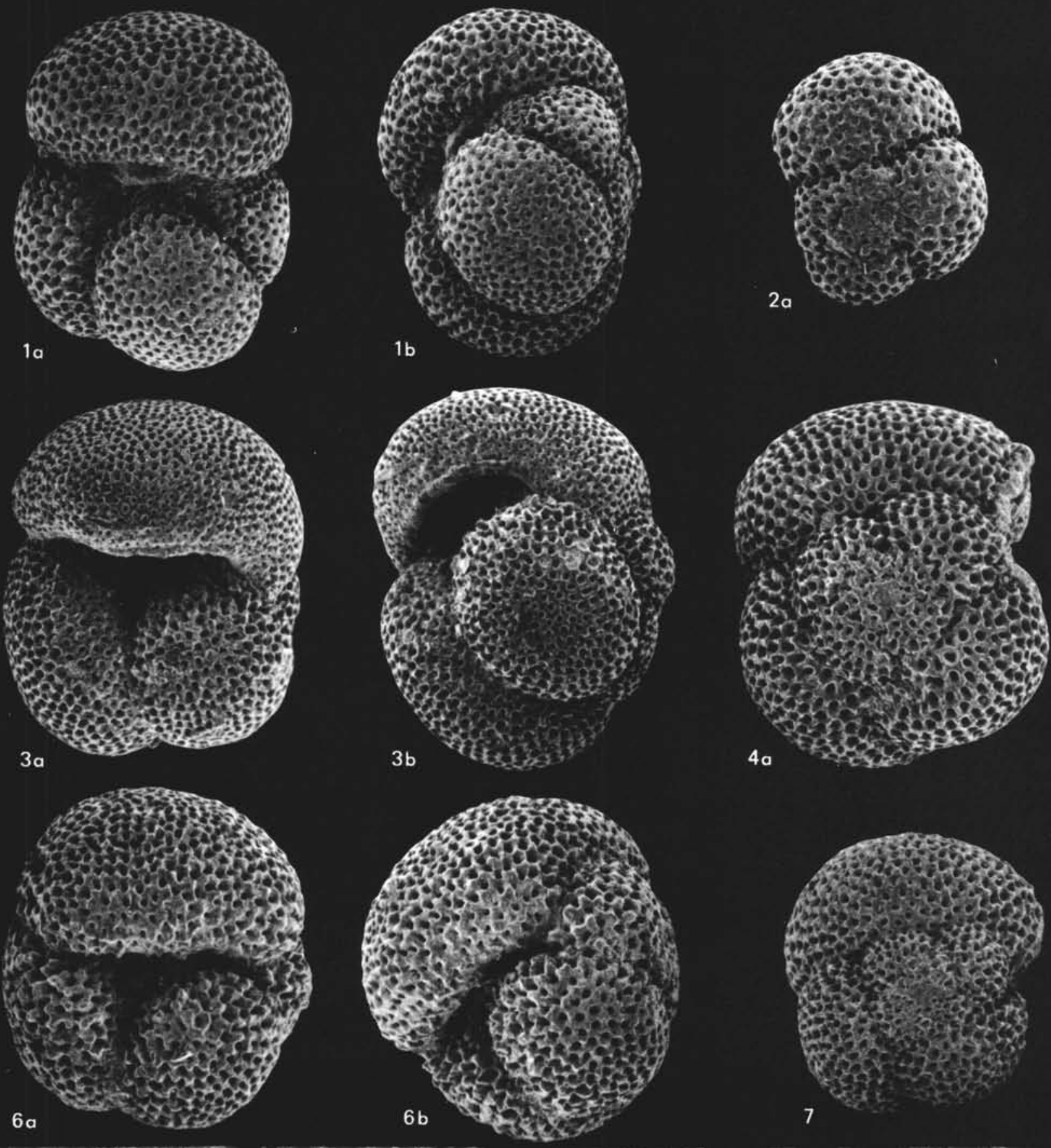

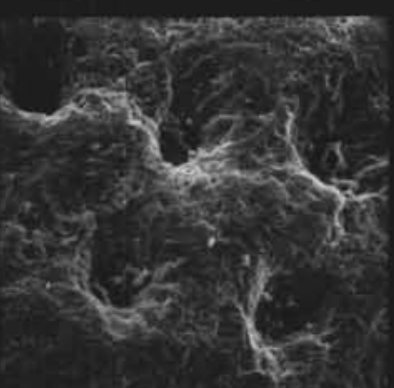

$2 b$

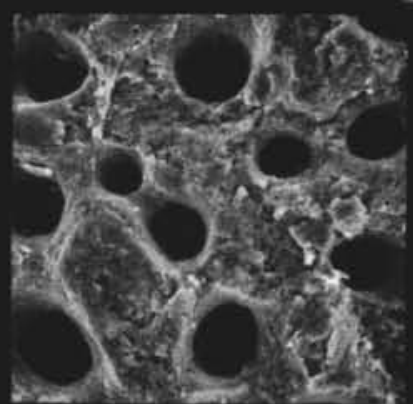

5

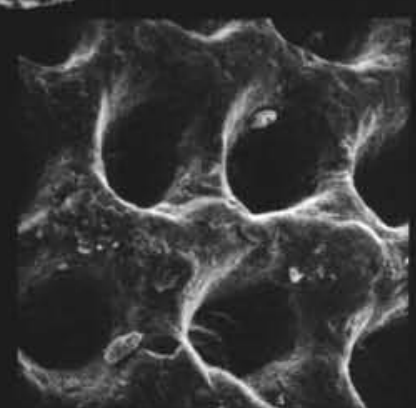

$4 b$
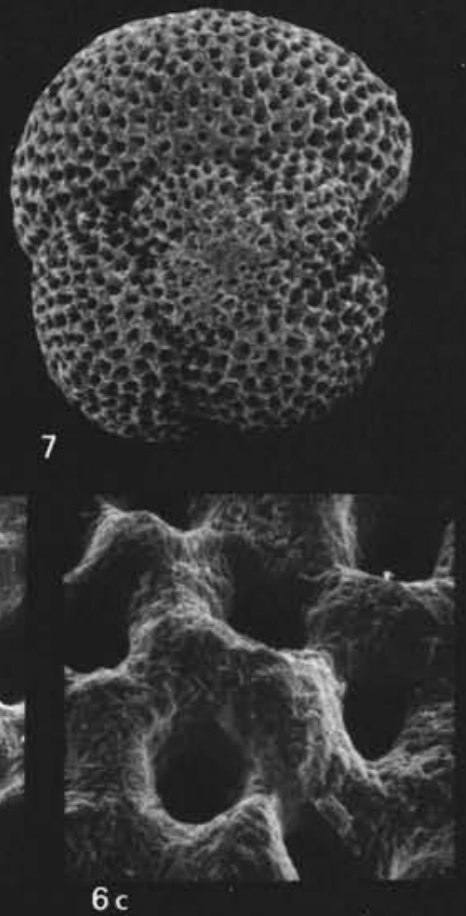


\section{PLATE 4}

Figures 1,2 Globigerina officinalis Subbotina.

Sample 369A-28-2, 61-63 cm, Oligocene.

1. Umbilical view, $\times 150$.

2a. Peripheral view, $\times 150$.

2b. Spiral view, $\times 150$.

2c. Ultrastructure of the spiral side of the last chamber, $\times 1000$.

Figures 3-5 Globigerina angiporoides Hornibrook.

Sample 369A-30-1, 71-73 cm, Oligocene.

3. Umbilical view, $\times 150$.

4. Peripheral view, $\times 150$.

5a. Spiral view, $\times 150$.

$5 \mathrm{~b}$. Ultrastructure of the spiral side of the last chamber, $\times 1000$.

Figure 6 Globigerina senilis Bandy.

Sample 369A-29-1, 61-63 cm, Oligocene.

6a. Spiral view, $\times 150$.

6b. Ultrastructure of the spiral side of the last chamber, $\times 1000$.

Figures 7,8 Globigerina aff. senilis Bandy.

Sample 369A-29-1, 61-63 cm, Oligocene.

7. Peripheral view, $\times 150$.

8a. Umbilical view, $\times 150$.

8 b. Ultrastructure of the umbilical side of the last chamber, $\times 1000$.

Figures 9-11 Globigerina ouachitaensis ouachitaensis Howe and Wallace.

Sample 369A-19, CC, Oligocene.

9. Umbilical view, $\times 150$.

10. Peripheral view, $\times 150$.

11a. Spiral view, $\times 150$.

11b. Ultrastructure of the spiral side of the last chamber, $\times 1000$. 


\section{PLATE 4}
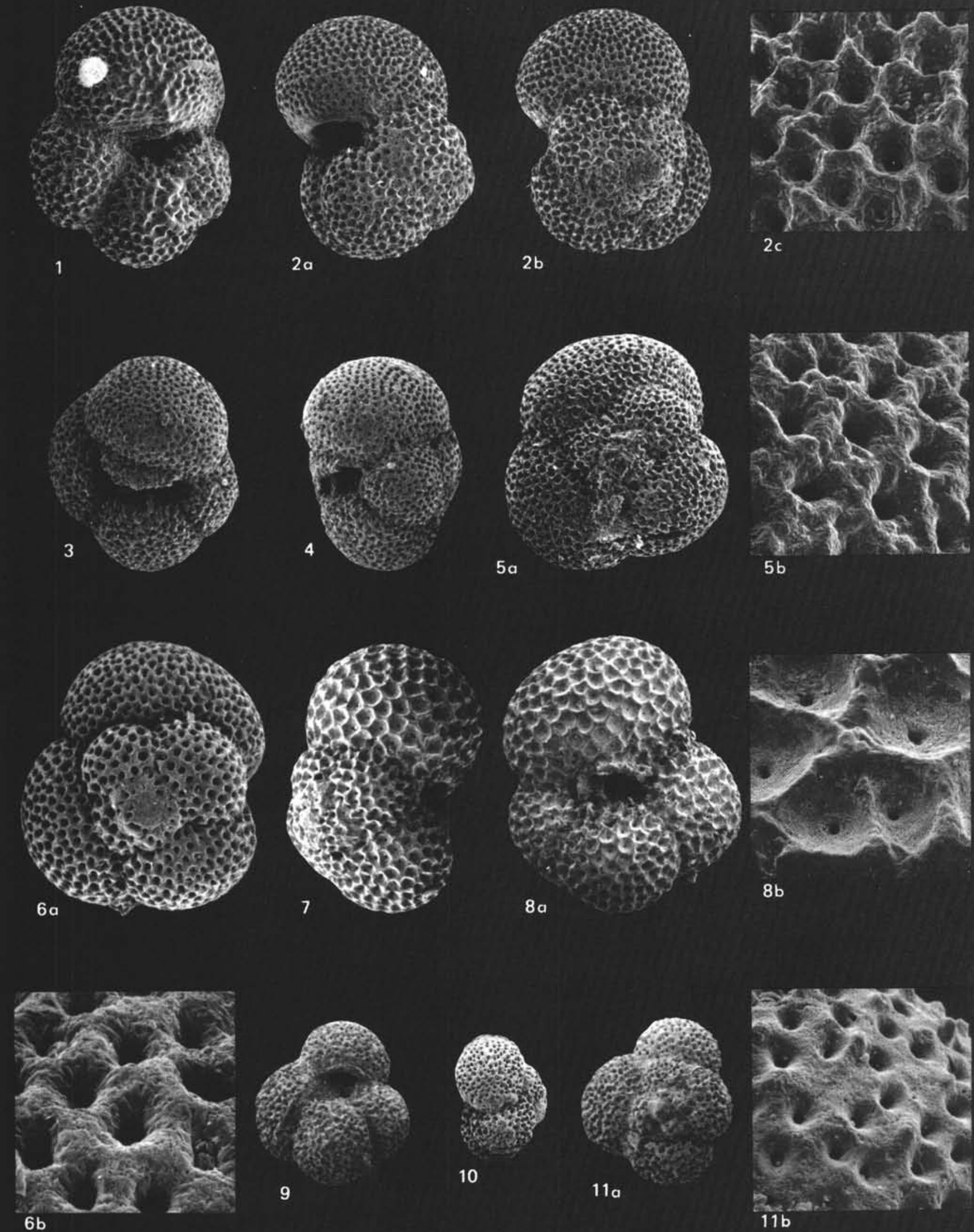


\section{PLATE 5}

Figures 1-3 Globigerina anguliofficinalis Blow.

Sample 369A-29-1, 61-63 cm, Oligocene.

1a. Spiral view, $\times 150$.

1b. Ultrastructure of the spiral side of the last chamber, $\times 1000$.

2. Peripheral view, $\times 150$.

3a. Umbilical view, $\times 150$.

$3 \mathrm{~b}$. Ultrastructure of the umbilical side of the last chamber, $\times 1000$.

Figures 4, $5 \quad$ Globorotalia (?) brevispira (Subbotina).

Sample 369A-27-2, 101-103 cm, Oligocene.

4a. Umbilical view, $\times 150$.

4b. Ultrastructure of the umbilical side of the last chamber, $\times 1000$.

5a. Peripheral view, $\times 150$.

5 b. Spiral view, $\times 150$.

5c. Ultrastructure of the spiral side of the penultimate chamber, $\times 1000$.

Figures 6-8 Globigerina rohri Bolli.

Sample 369A-22, CC, Oligocene.

6a. Spiral view, $\times 75$.

$6 \mathrm{~b}$. Ultrastructure of the spiral side of the penultimate chamber, $\times 1000$.

7. Peripheral view, $\times 75$.

8. Umbilical view, somewhat oblique to the axis, $\times 75$.

Figures 9-11 Globorotalia gemma Jenkins.

Sample 369A-28-4, 61-63 cm, Oligocene.

9. Spiral view, $\times 375$.

10. Peripheral view, $\times 375$.

11a. Umbilical view, $\times 375$.

11b. Ultrastructure of the umbilical side of the last chamber, $\times 1000$. 


\section{PLATE 5}

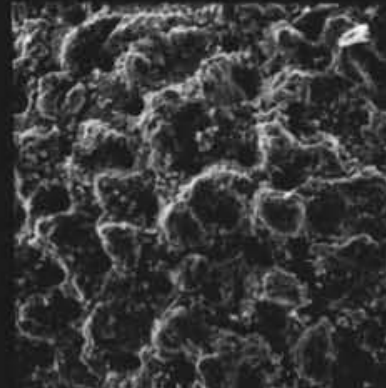

$1 \mathrm{~b}$

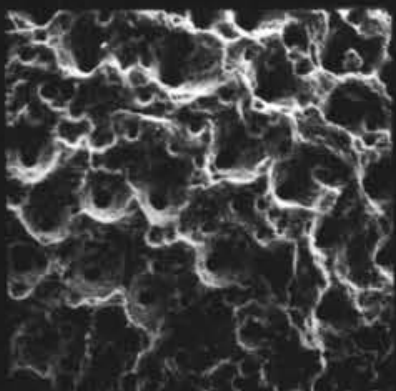

$4 b$

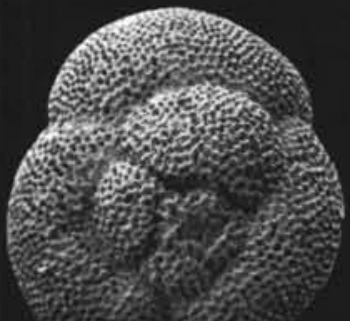

$6 a$

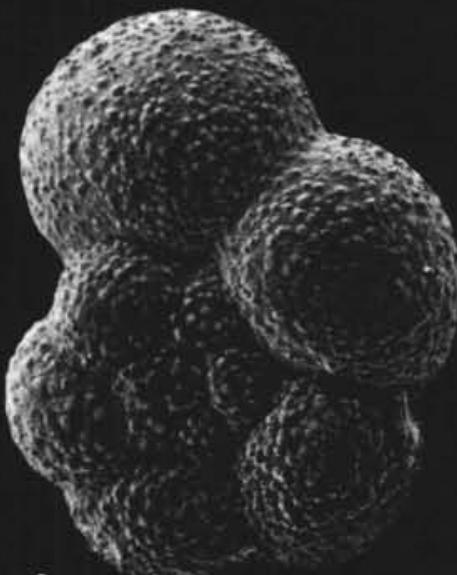

9

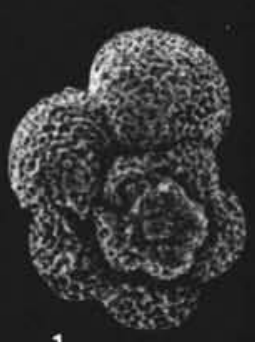

1a

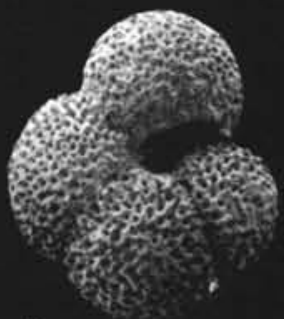

$4 a$

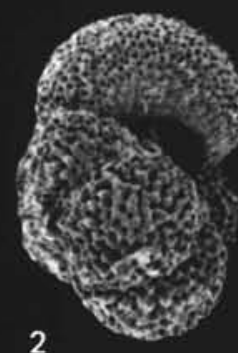

$5 a$

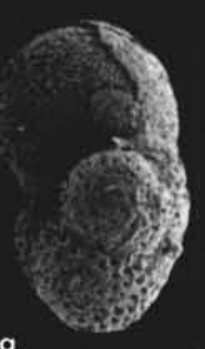

$5 b$
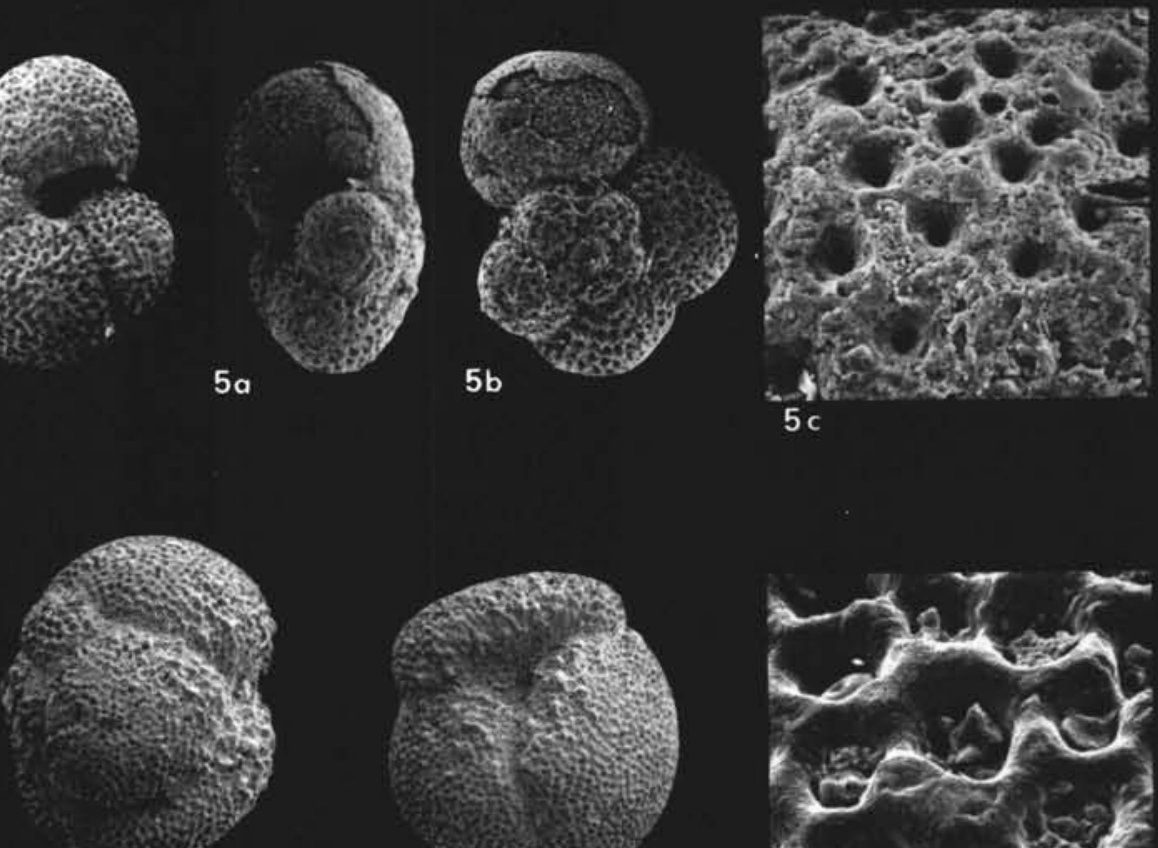

7

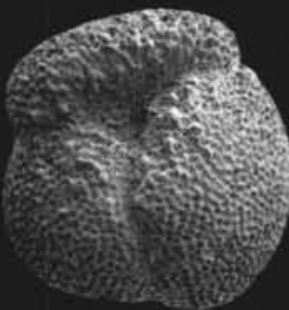

8

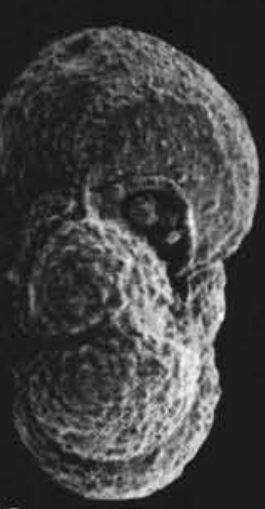

$11 \mathrm{a}$

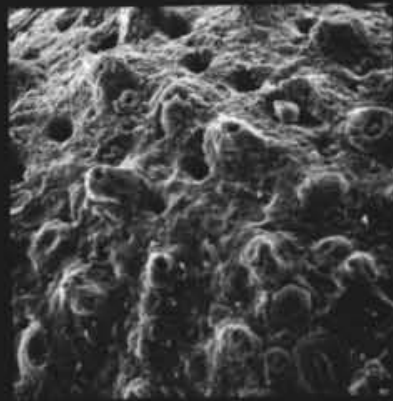

$3 b$ $5 c$

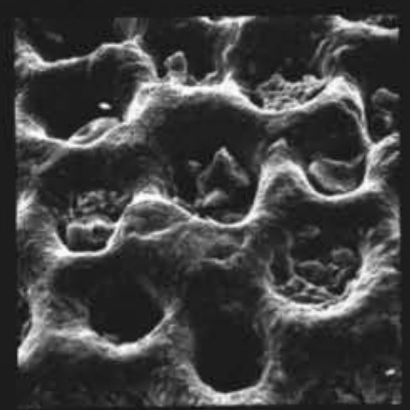

$6 b$
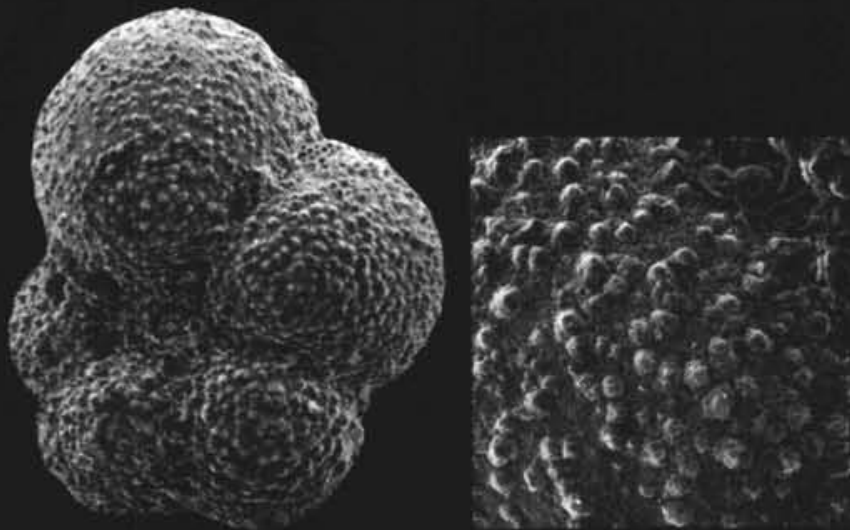

$11 b$ 


\section{PLATE 6}

Figures 1-3 Globorotalia kugleri Bolli.

Sample 366A-28-2, 65-67 cm, Oligocene.

1a. Umbilical view, $\times 150$.

1b. Ultrastructure of the umbilical side of the last chamber, $\times 1000$.

2. Peripheral view, $\times 150$.

3a. Spiral view, $\times 150$.

3b. Ultrastructure of the spiral side of the last chamber, $\times 1000$.

Figures 4-6 Globorotalia pseudokugleri Blow.

Sample 366A-29-4, 48-50 cm, Oligocene.

4a. Umbilical view, $\times 150$.

4b. Ultrastructure of the umbilical side of the last chamber, $\times 1000$.

5. Peripheral view, $\times 150$.

6a. Spiral view, $\times 150$.

6b. Ultrastructure of the spiral side of the last chamber, $\times 1000$.

Figures 7-9 Globorotalia opima Bolli.

Sample 369A-22, CC, Oligocene.

7. Spiral view, $\times 150$.

8. Peripheral view, $\times 150$.

9a. Umbilical view, $\times 150$.

9b. Ultrastructure of the umbilical side of the last chamber, $\times 1000$.

Figures 10,11 Globorotalia nana Bolli.

Sample 369A-28-4, 61-63 cm, Oligocene.

10. Umbilical view, $\times 150$.

10b. Ultrastructure of the umbilical side of the last chamber, $\times 1000$.

11a. Spiral view, $\times 150$.

11b. Peripheral view, $\times 150$.

11c. Umbilical view, $\times 150$.

Figures 12-14 Globorotalia permicra Blow and Banner.

Sample 369A-28-2, 61-63 cm, Oligocene.

12a. Spiral view, $\times 375$.

$12 \mathrm{~b}$. Ultrastructure of the spiral side of the last chamber, $\times 1000$.

13. Peripheral view, $\times 375$.

14a. Umbilical view, $\times 375$.

14b. Ultrastructure of the umbilical side of the last chamber, $\times 1000$. 


\section{PLATE 6}
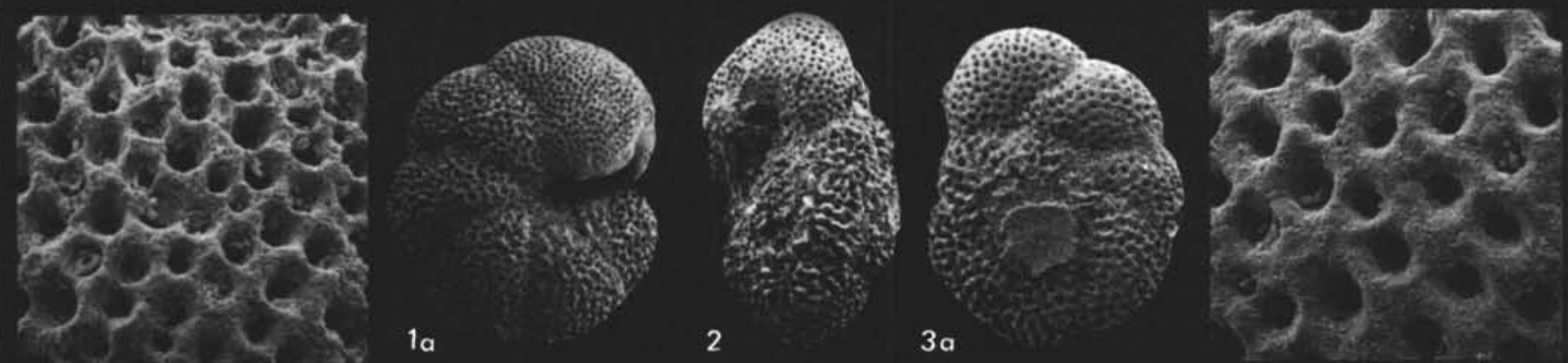

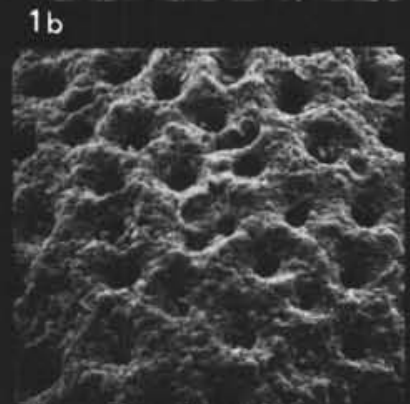

1a

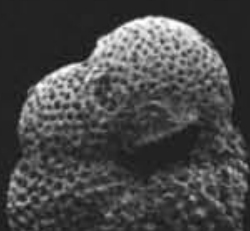

$4 a$

5
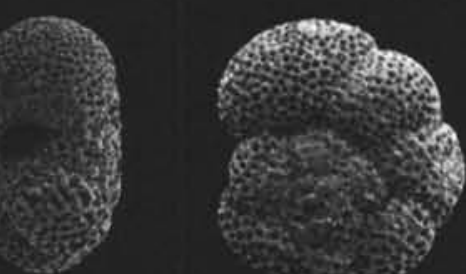

a

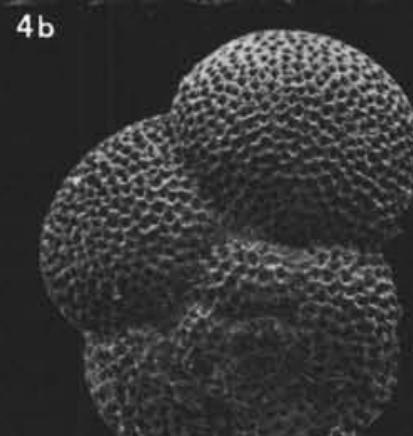

7

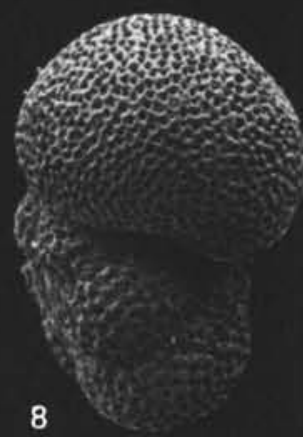

$9 a$

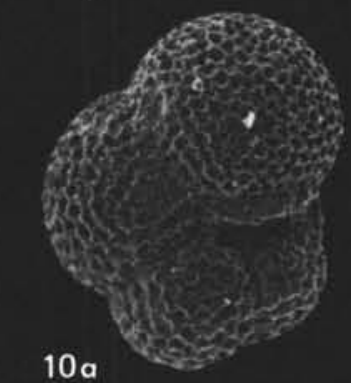

110

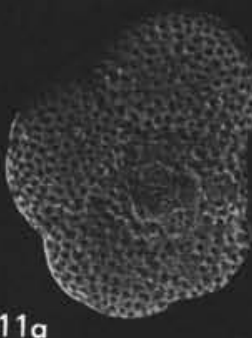

$11 \mathrm{~b}$
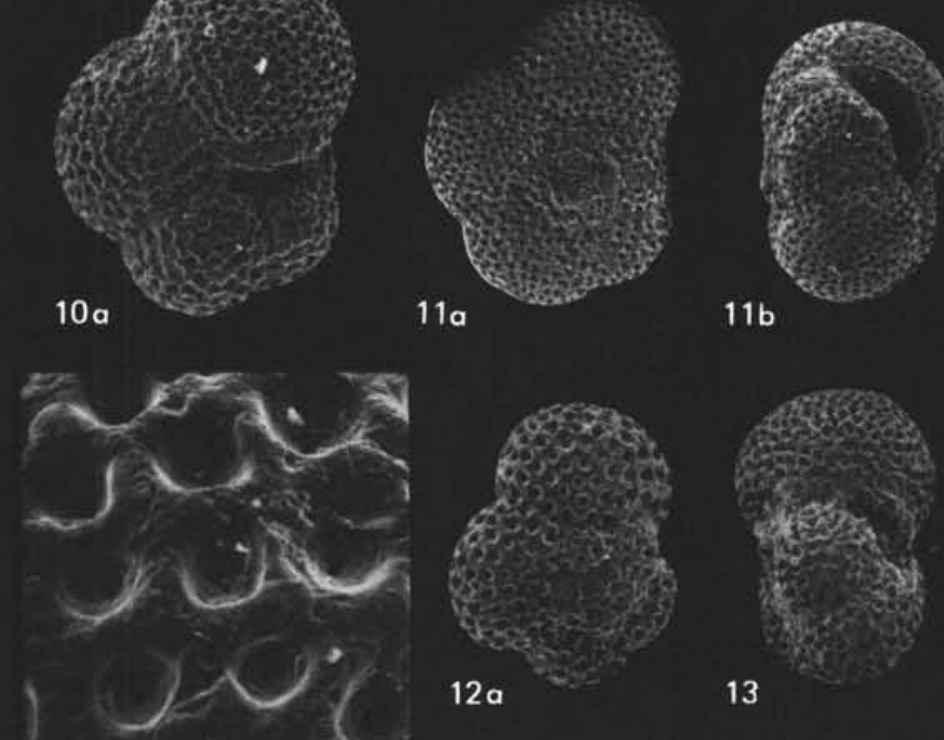

$12 b$

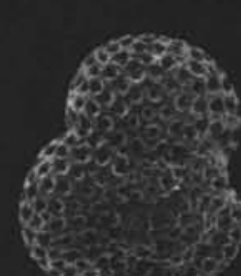

$12 a$

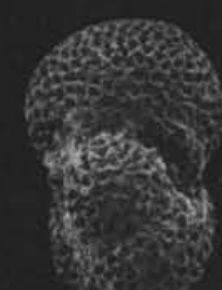

13
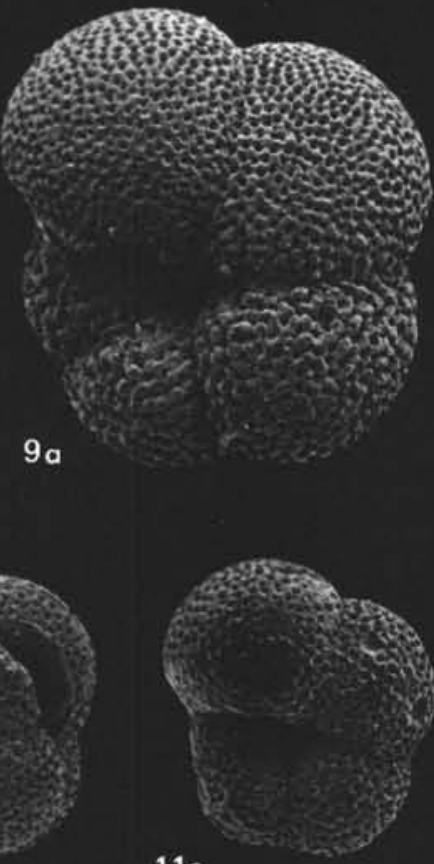

$11 c$

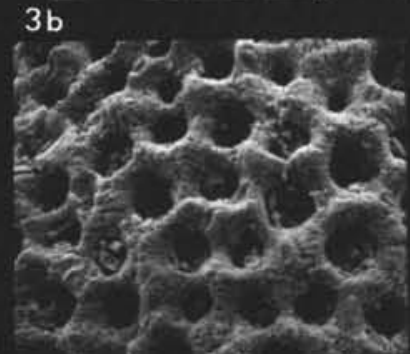

6

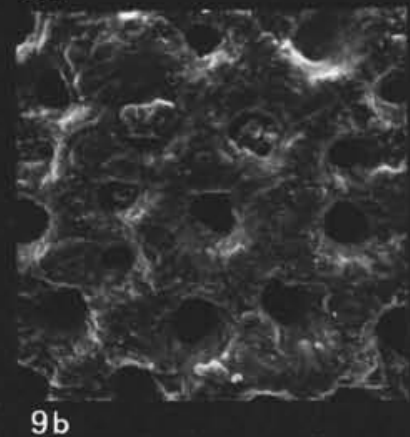

9

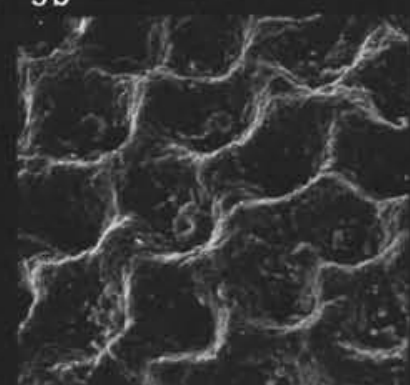

$10 \mathrm{~b}$

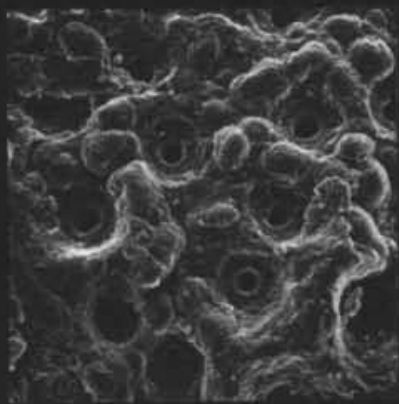

$14 b$ 


\section{PLATE 7}

Figure $1 \quad$ Globigerina stainforthi praestainforthi Blow.

Sample 369A-18, CC, Oligocene.

1a. Umbilical view, $\times 75$.

1b. Peripheral view, $\times 75$.

1c. Spiral view, $\times 75$.

1d. Ultrastructure of the umbilical side of the last normal chamber, $\times 1000$.

Figures 2, 3 Globigerinita dissimilis (Cushman and Bermudez). Sample 369A-21, CC, Oligocene.

2. Spiral view, $\times 75$.

3a. Peripheral view, $\times 75$.

3b. Umbilical view, $\times 75$.

3c. Ultrastructure of the umbilical side of the last chamber, $\times 1000$.

3d. Ultrastructure of the bulla, $\times 1000$.

Figures 4-6 Globigerinita unicava (Bolli, Loeblich and Tappan).

Sample 369A-30-1, 71-73 cm, Oligocene.

4a. Spiral view, $\times 150$.

4b. Ultrastructure of the spiral side of the last chamber, $\times 1000$.

5. Peripheral view, $\times 150$.

6a. Umbilical view, $\times 150$.

6b. Ultrastructure of the umbilical side of the last chamber, $\times 1000$.

6c. Ultrastructure of the bulla, $\times 1000$.

Figures 7-9 Globorotaloides suteri Bolli.

Sample 369A-19-1, 85-87 cm, Oligocene.

7a. Spiral view, $\times 150$.

7b. Ultrastructure of the spiral side of the last chamber, $\times 1000$.

8. Peripheral view, $\times 150$.

9a. Umbilical view, $\times 150$.

9b. Ultrastructure of the umbilical side of the last chamber, $\times 1000$.

9c. Ultrastructure of the bulla, $\times 1000$. 


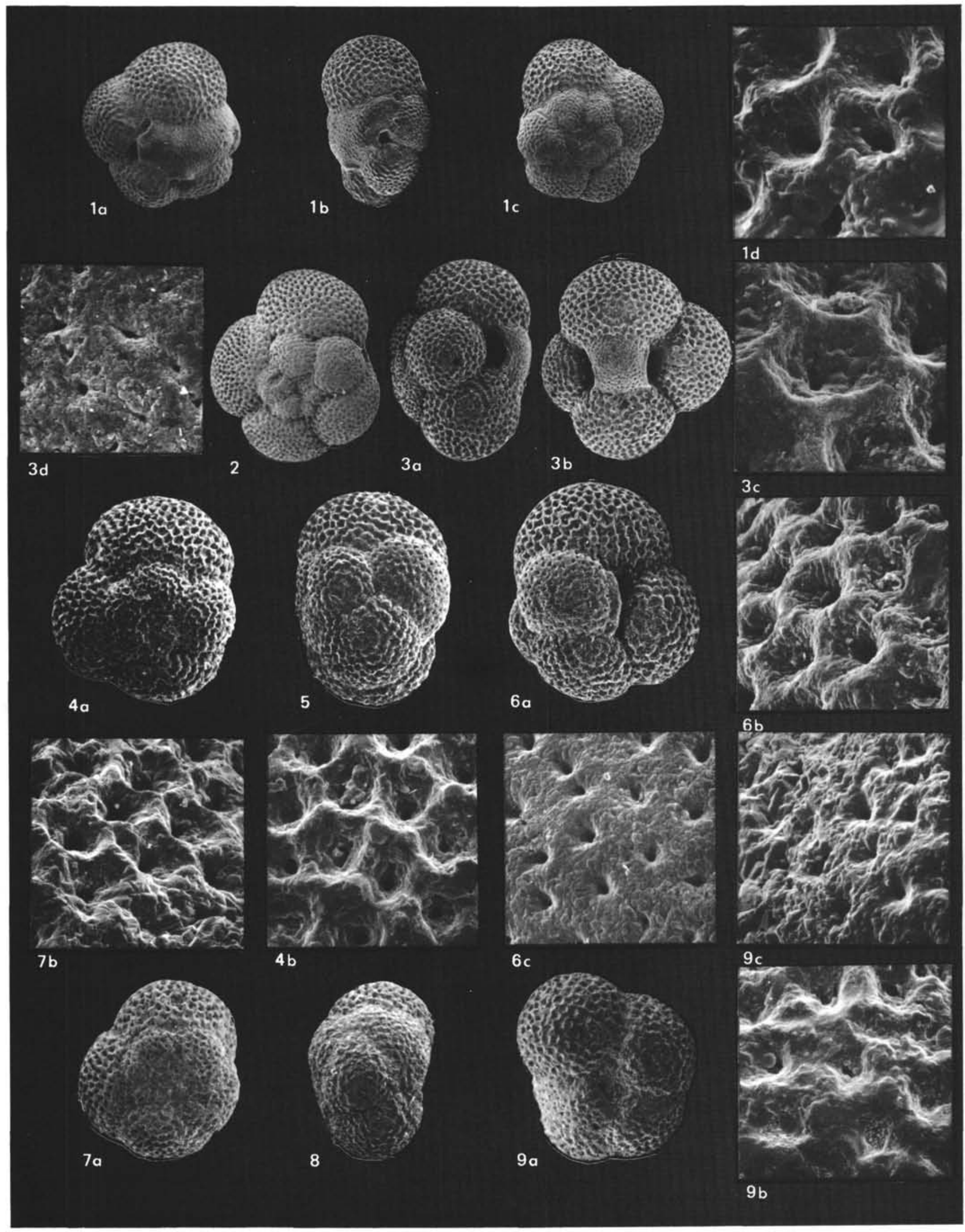




\section{PLATE 8}

Figures 1-3 Pseudohastigerina barbadoensis Blow. Sample 369A-29-2, 61-63 cm, Oligocene.

1a. Lateral view, $\times 300$.

1b. Ultrastructure of the last chamber, $\times 1000$.

2. Peripheral view, $\times 300$.

3. Lateral view, $\times 300$.

Figures 4-6 Pseudohastigerina micra (Cole).

Sample 369A-28, CC, Oligocene.

4a. Lateral view of a specimen transitional to P. barbadoensis, $\times 300$.

4b. Ultrastructure of the last chamber, $\times 1000$.

5. Peripheral view, $\times 300$.

6. Lateral view, $\times 300$.

Figures 7,8 Cassigerinella chipolensis (Cushman and Ponton). Sample 369A-28, CC, Oligocene.

7a. Oblique umbilical-apertural view, $\times 300$.

$7 \mathrm{~b}$. Ultrastructure of the last chamber, $\times 1000$.

8 a. Oblique umbilical-apertural view, $\times 300$.

8 b. Ultrastructure of the penultimate chamber, $\times 1000$.

Note: Two different types of holes: small ones at the lower part of the figure, big ones, surrounded by a collar, mainly at the peripheral parts of the test.

Figures 9, 10 Chiloguembelina aff. cubensis (Palmer).

Sample 369A-28-5, 71-73 cm, Oligocene.

9 a. Lateral view, $\times 300$.

$9 \mathrm{~b}$. Ultrastructure of the last chamber near the aperture, $\times 1000$.

10a. Peripheral view, $\times 300$.

10b. Ultrastructure of the penultimate chamber, peripheral part, $\times 1000$. 


\section{PLATE 8}
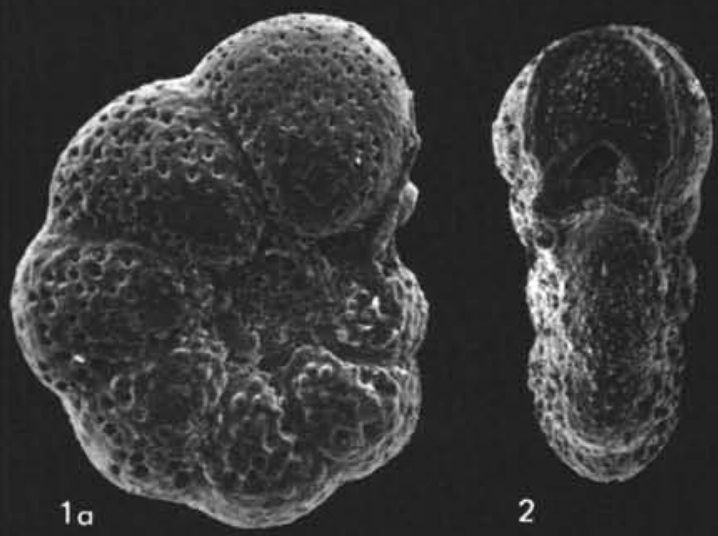

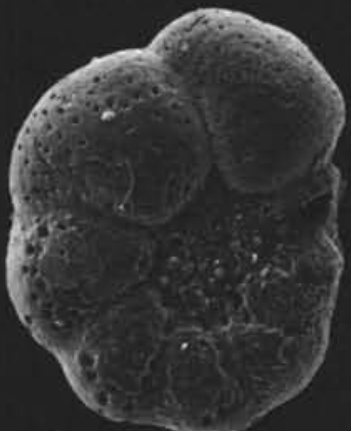

$4 \mathrm{a}$

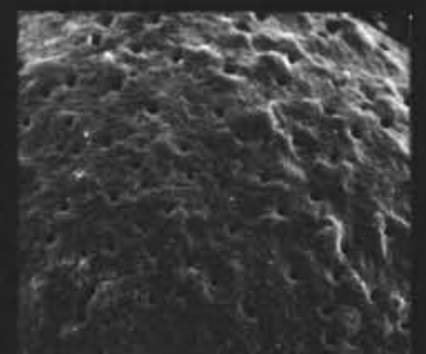

$7 b$

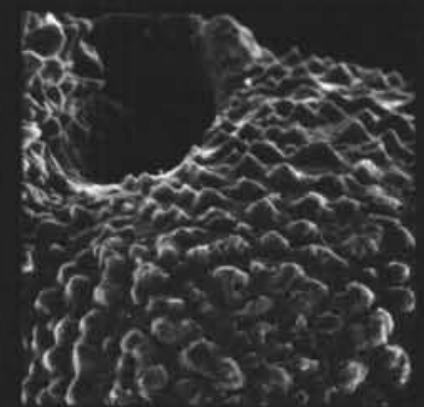

$9 \mathrm{~b}$
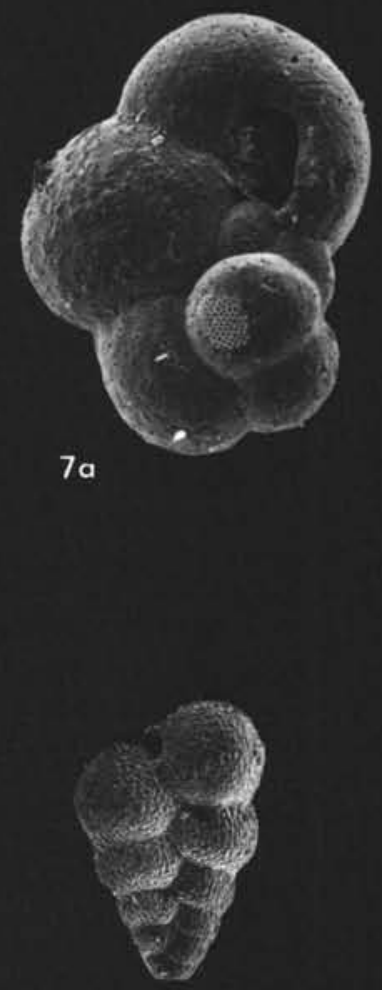

$9 a$
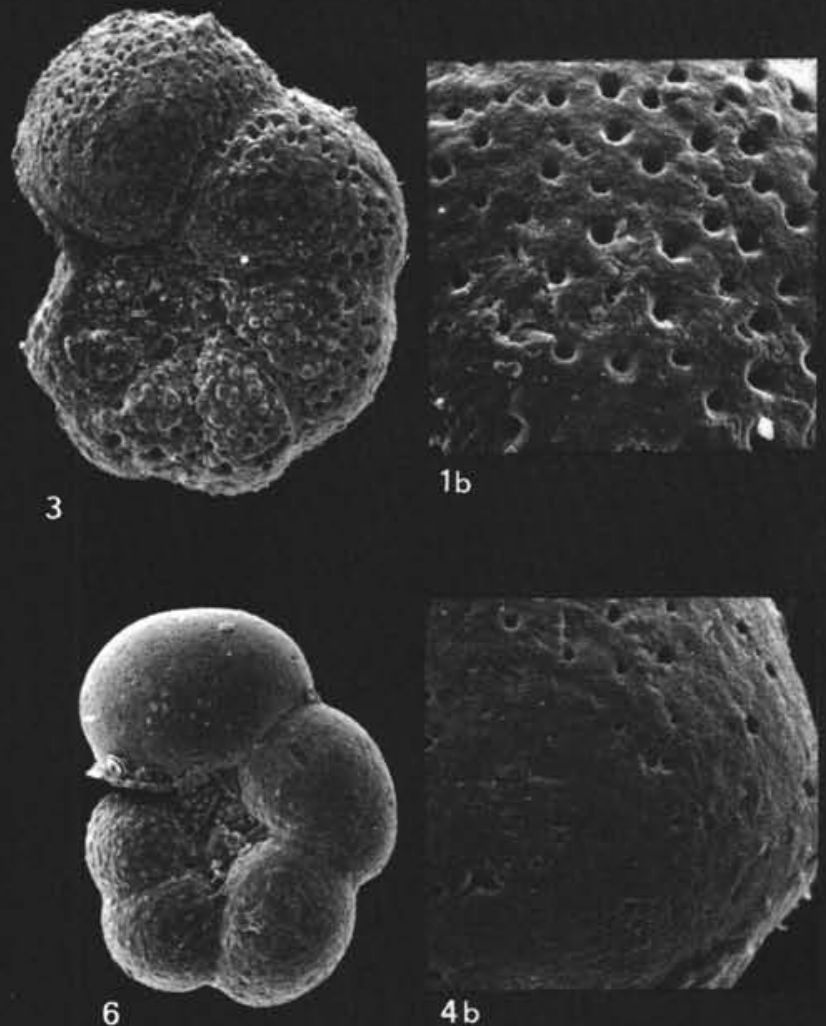

$4 b$

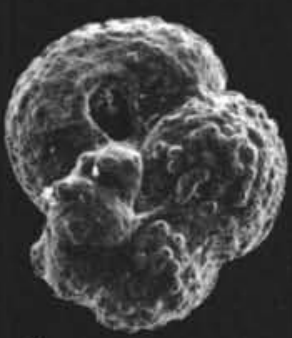

$8 a$

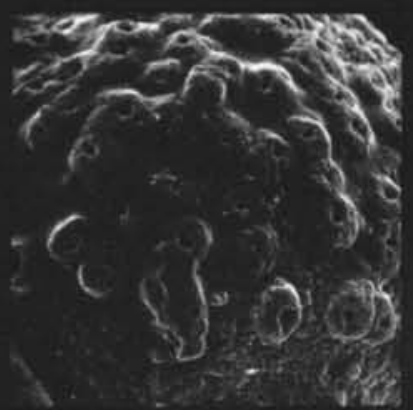

$8 b$
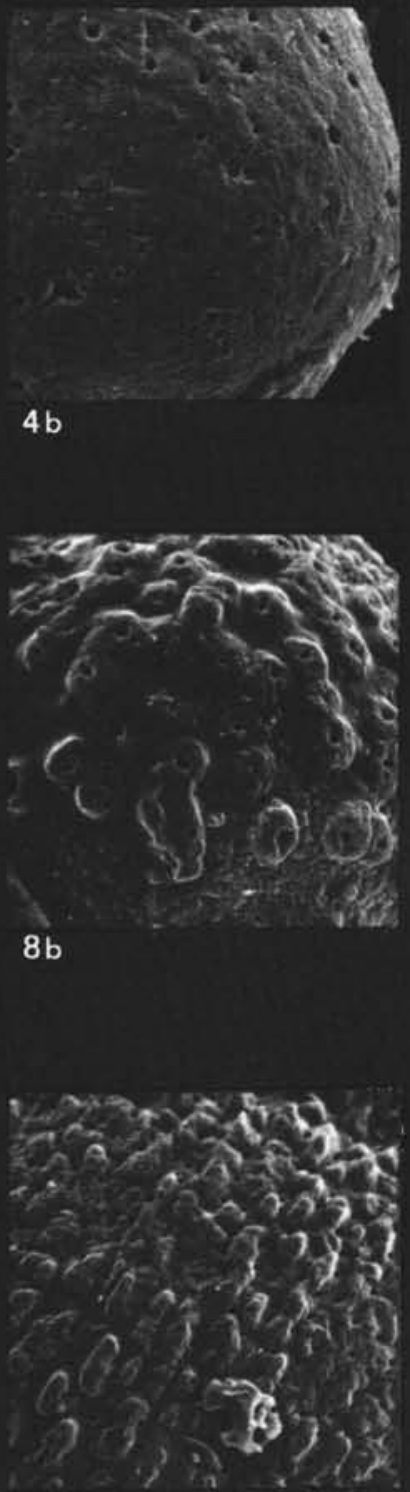

$10 a$

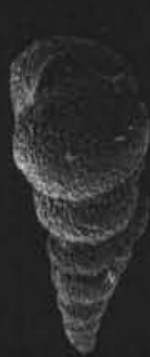

